\title{
Oltre la visione: percezione, conoscenza, disegno, narrazione
}

\author{
Pia Davico
}

\section{Abstract}

Quando diseginamo l'ambiente che ci circonda, per rilevarlo, conoscerlo o immortalarne quanto più ci ha colpito, ciò che tracciamo sul foglio non rimane estraneo alle nostre emozioni, più o meno controllate e consapevoli, che completano e interpretano il prevalente riferimento ai caratteri materiali colti visivamente. II disegno, per la sua versatilità espressiva, è infatti lo strumento più adatto a esprimere quanto deriva dalla nostra conoscenza o percezione, integrato con altri stimoli che completano quelli della visione.

Su questo presupposto si fonda l'esperienza didattica di un Workshop che qui presento. II disegno vi ha narrato gli aspetti del Borgo Medievale di Torino a varie scale di osservazione e conoscenza, ed è stato affiancato da un'esperienza percettiva inizialmente al buio, in cui la vista è stata annullata per meglio capire quanto un non vedente colga dell'ambiente che lo circonda. Le sensazioni provate da docenti e studenti hanno poi supportato il tentativo di narrare (con un linguaggio grafico-pittorico volutamente non richiesto di definire con precisione le forme) quanto un architetto oggi non vedente ha percepito e colto dei luoghi visitati insieme. L'inedita esperienza (che ritengo interpreti lo spirito di questo Convegno) ha sensibilizzato i futuri architetti nel progettare con maggiore consapevolezza e sensibilità, e ha permesso a ciascuno dei partecipanti di dare voce attraverso il disegno alle proprie sensazioni e ai propri sentimenti.

Parole chiave

disegno, percezione visiva, conoscenza, cecità, narrazione grafico-espressiva.

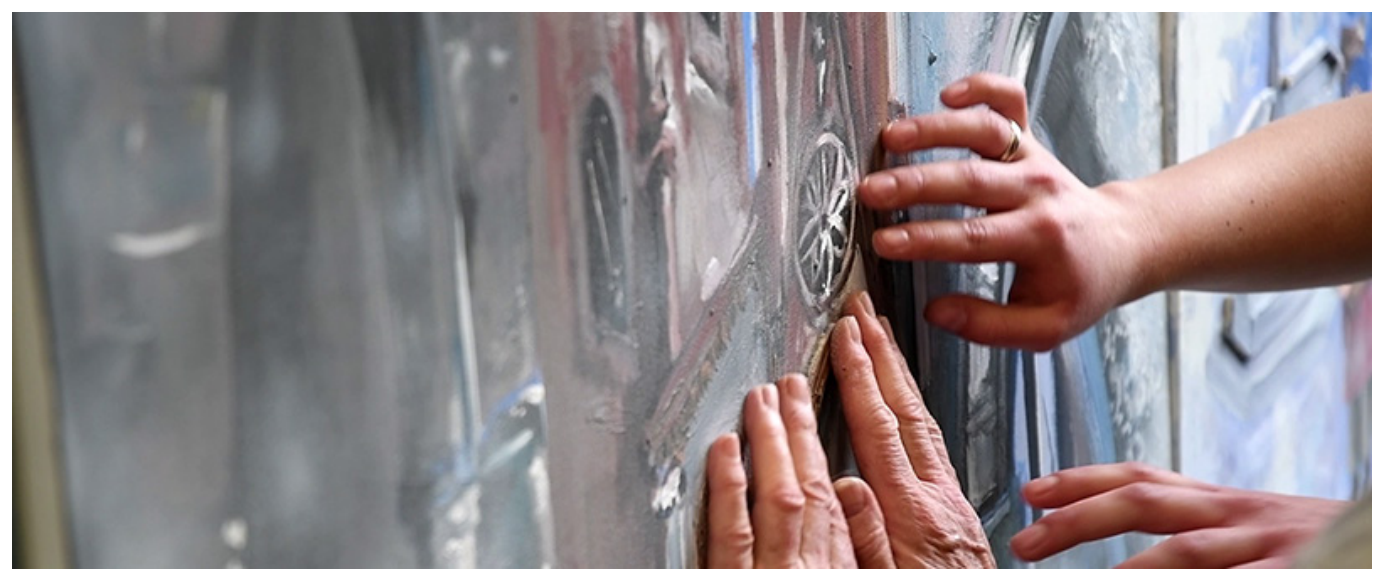




\section{Introduzione}

Alcune frasi nella presentazione di questo Convegno mi hanno subito portata a ritrovarne il significato in un lavoro didattico che ho proposto alcuni mesi fa nel Workshop "Osservo, creo, racconto. Dialoghi tra Arte/Artistico e Architettura. Dal disegno alla fotografia al video". In esso, come ormai da alcuni anni, ho inteso far lavorare insieme studenti della triennale di Architettura del Politenico di Torino e del Liceo Artistico Cottini, affinché attraverso il comune interesse per il disegno sperimentassero nuove dinamiche grafico-espressive, creando un dialogo arricchente tra allievi di due realtà formative differenti. Quest'intento, pienamente raggiunto durante il Workshop, trova appunto riscontro nella frase "un eterno luogo di dialoghi [...] nella eterna ricerca del superamento dei conflitti e delle divisioni"; il significato si amplifica nell'esperienza 'Oltre la visione', integrata tra le attività del Workshop. Un'esperienza innovativa, accomunata dal disegno e tesa a sviluppare attenzione e sensibilità sia alla percezione dei luoghi sia al tema della cecità, mettendone in risalto aspetti a mio giudizio fondamentali nella formazione, professionale e umana, di ragazzi per i quali la visione, le immagini e la comprensione di quanto li circonda devono risultare fattori strettamente interconnessi.

Gli studenti, lavorando sul Borgo Medievale di Torino durante tutta l'attività laboratoriale, hanno potuto conoscerlo in un modo nuovo soprattutto attraverso le parole dell'architetto Grazia Baroni, già docente di Storia dell'arte e divenuta non vedente una decina di anni fa, che li ha accompagnati a 'vedere con i suoi occhi' il borgo, in un faticoso equilibrio tra i ricordi e quanto lei oggi percepisce non avendo più l'uso della vista.

È stata una breve esperienza, ma coinvolgente per i ragazzi nel sensibilizzarli a comprendere in quanti modi diversi si può 'vedere' la realtà: un punto di partenza, in specie per i futuri architetti, avvicinati a cogliere la soggettività percettiva di molti aspetti del contesto esaminato e il variabile rapporto tra le sue parti, nonché le sue congruenze e incongruenze fisiche e funzionali. E' risultato altresì uno stimolo per tutti gli studenti a cercare nuove strade e modalità espressive per individuare e narrare le diversità, imparando a dialogare e a superare eventuali divergenze preconcette.

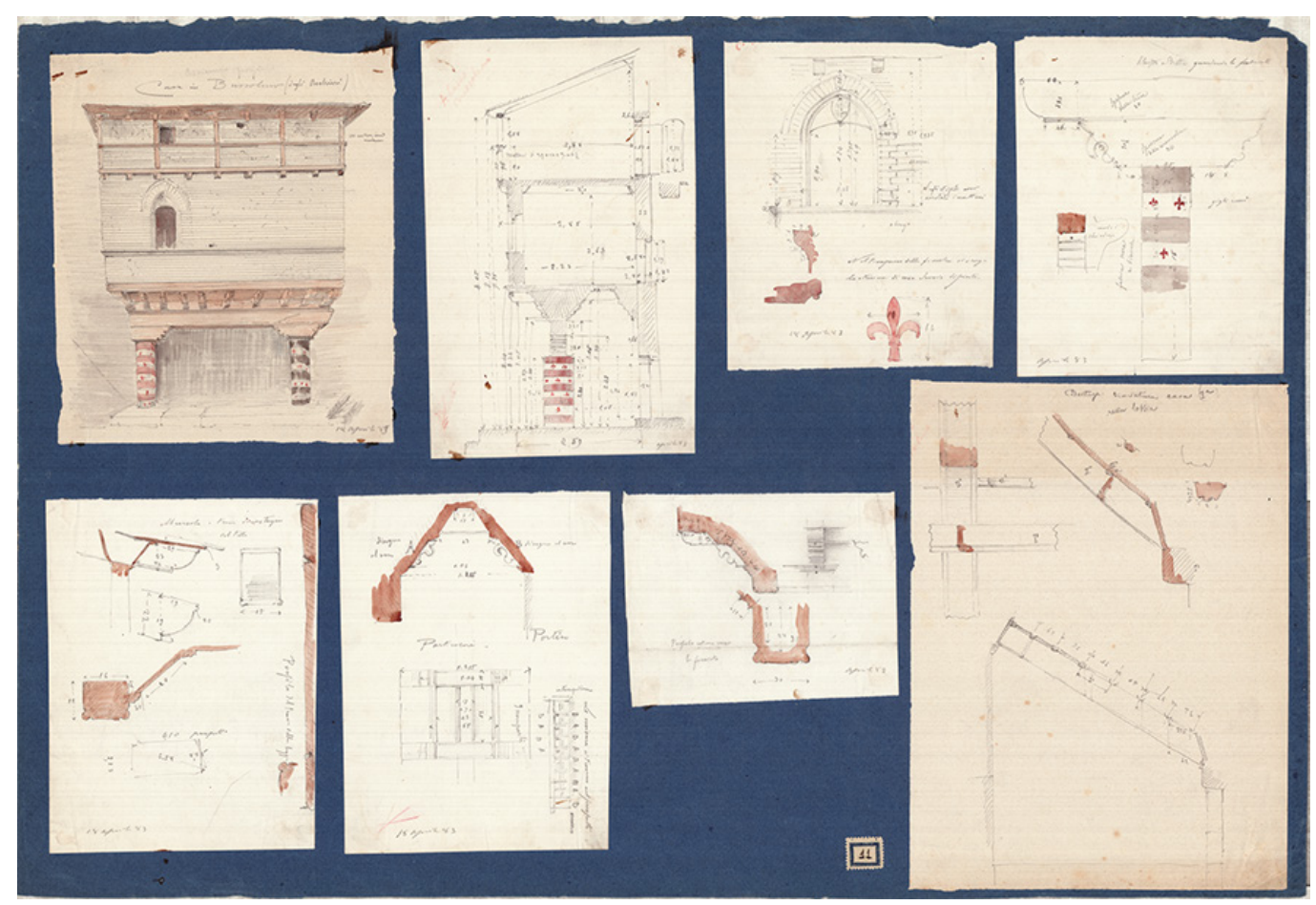




\section{Il disegno del Borgo Medievale di Torino}

In questa sorta di laboratorio 'veloce' i ragazzi sono stati guidati da me e dal gruppo di lavoro [I] a conoscere e a raccontare graficamente, in pochi giorni, uno dei luoghi più suggestivi della città, immerso nel verde del Parco del Valentino, in cui l'architettura e l'articolazione tortuosa dell'impianto urbano rievocano un ambiente medievale, isolato in una identità sospesa nel tempo. II complesso si rifa al progetto realizzato da Alfredo D'Andrade per la Sezione di Arte Antica dell'Esposizione Generale Italiana di Torino del I884, in cui venne riprodotto un borgo feudale del $X V$ secolo con il suo castello [2]. II nucleo fu concepito con caratteri fortemente innovativi (e come tali ampiamente discussi) perché si discostava dal tradizionale modello di mostra antiquariale, proponendo invece un "saggio intorno la vita civile e militare del Piemonte nel secolo XV, mediante una raccolta di fabbriche arredate, disposte a modo di Castello (cioè Borgo colla dominante Rocca)" [3]; le tecniche costruttive e ogni elemento compositivo e decorativo dell'edificato, nonché gli stessi oggetti d'uso e dell'arredo, riproducevano fedelmente i modelli originali, testimoniando la coeva riscoperta dell'architettura e dell'arte medievale proposti a livello internazionale da Eugène Viollet-leDuc e da William Morris.

II Borgo propone infatti un villaggio, circondato da una cinta difensiva merlata e semidiroccata protetta dal fossato, sul quale emergono il castello e la torre-porta con ponte levatoio. È tuttora una realtà quasi fiabesca, circondata dal parco e affacciata sulla sponda del Po, particolarmente interessante da scoprire, da vivere, e da disegnare. La connotazione ambientale, equilibrata tra costruito e naturale, è dovuta all'attenta riproposizione di ambienti, architetture e dettagli fedeli agli originali, riprodotti con precisione filologica dopo una minuziosa campagna di rilievo dello stesso D'Andrade e di altri [4] (figg. I, 2), di strutture medievali del Piemonte e della Val D'Aosta, documentati dai disegni tuttora conservati [Donato 2006]. II villaggio presenta un abile gioco scenografico, esplicitato sia dalla conformazione planivolumetrica - ad esempio nel gioco prospettico della via porticata per ampliarne percettivamente lo sviluppo o nella rocca in cima a un'altura - sia dalle case realizzate solo sul fronte come vere quinte teatrali (fanno eccezione la Casa di Avigliana e quella di Borgofranco interamente costruite). A rendere vivo e realistico il nucleo contribuiscono le botteghe

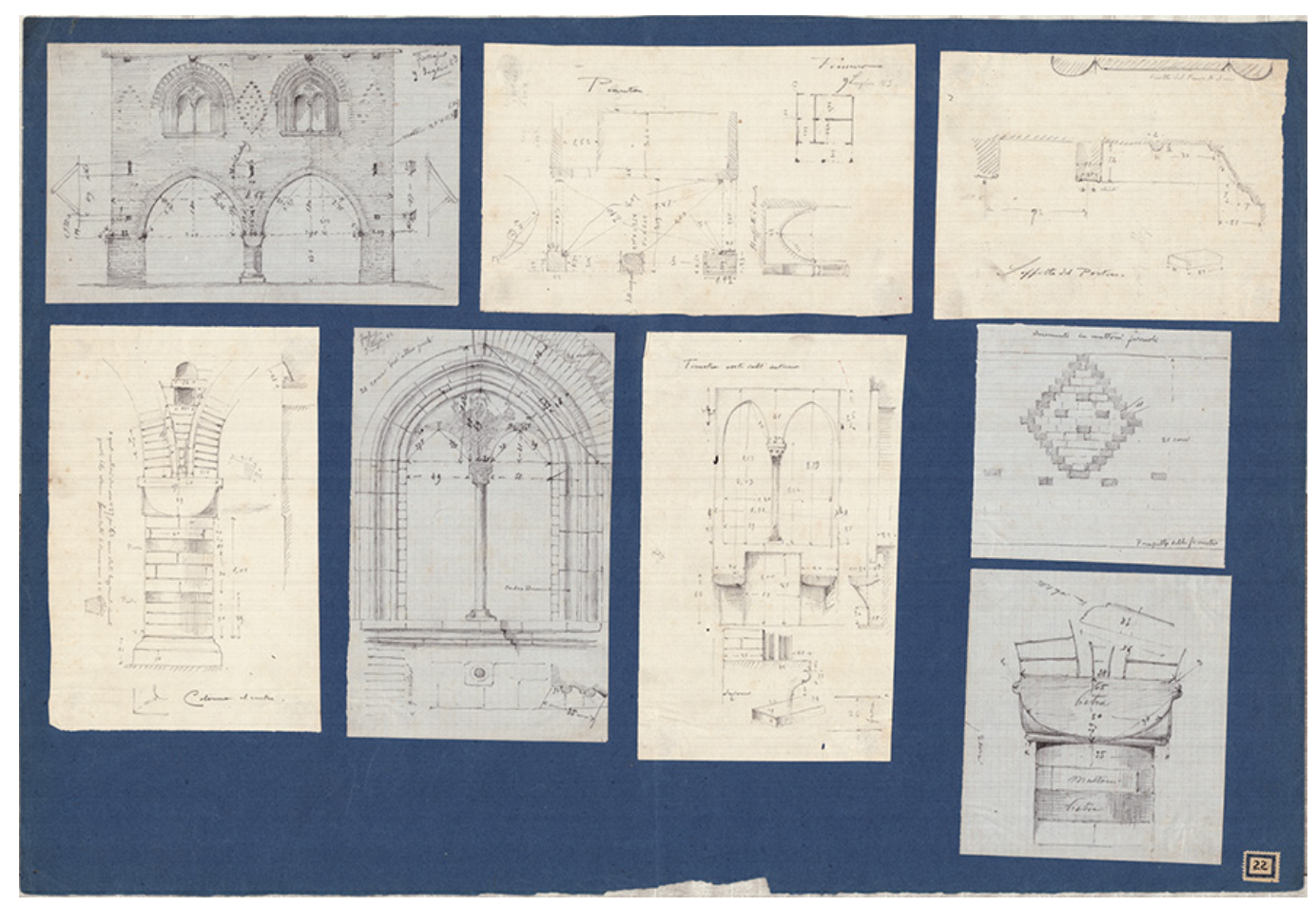


affacciate lungo la strada porticata, originariamente fruite per attività artigianali, che oggi richiamano l'atmosfera medievale per i suoni ovattati dei loro piccoli ambienti e del portico su cui si aprono, oppure, olfattivamente, per l'odore del cuoio che si propaga da una di esse. II luogo, dal fascino indiscutibile per la sua eccezionalità rispetto alla realtà urbana che lo circonda, è stato scelto per stimolare negli studenti la capacità di osservazione a più scale, dal paesaggio ai dettagli architettonici, cercando di coglierne anche gli aspetti immateriali caratterizzanti, aspetti vari che hanno poi cercato di trasmettere attraverso personali interpretazioni grafico-espressive. I disegni prodotti nei cinque convulsi giorni del Workshop esprimono infatti in sintesi quanto i ragazzi hanno percepito e conosciuto del Borgo, con una grafica cercata anche in tecniche per loro nuove, completata da fotografie e video, narrando suggestioni ambientali e architettoniche con vari linguaggi espressivi; il confronto e il dialogo tra studenti con formazioni diverse ha stimolato la creatività grafica di ciascuno come espressione del proprio pensiero (figg. 3-8). Questo percorso tra conoscenza e narrazione per immagini è stato completato dall'esperienza 'Oltre la visione', volta a considerare elementi anche immateriali che influenzano il modo di cogliere quanto ci circonda, volendo riflettere sulle proprie e altrui capacità percettive, basilari per chi progetterà architetture e luoghi e, al contempo, per avvicinarsi alla 'visione' di una persona cieca per comprendere quanto 'modi diversi di vedere' mettano in luce aspetti della realtà spesso non colti o tralasciati.

\section{Oltre la visione}

Questa inedita esperienza include aspetti della teoria del rilievo percettivo e si fonda sul presupposto che quando si guarda un luogo o un'architettura non si rimane estranei dal coinvolgimento emotivo procurato dall'aver percepito sensazioni al di là di quanto si è visto, il che nel disegno si riflette - anche involontariamente - nell'interpretazione grafica [Davico 2019; Chiavoni 20l8].

Sulla percezione di un luogo influisce infatti una moltitudine di sensazioni interrelate, che influenza il nostro modo di 'vedere'. Per scoprire almeno in parte ciò che normalmente

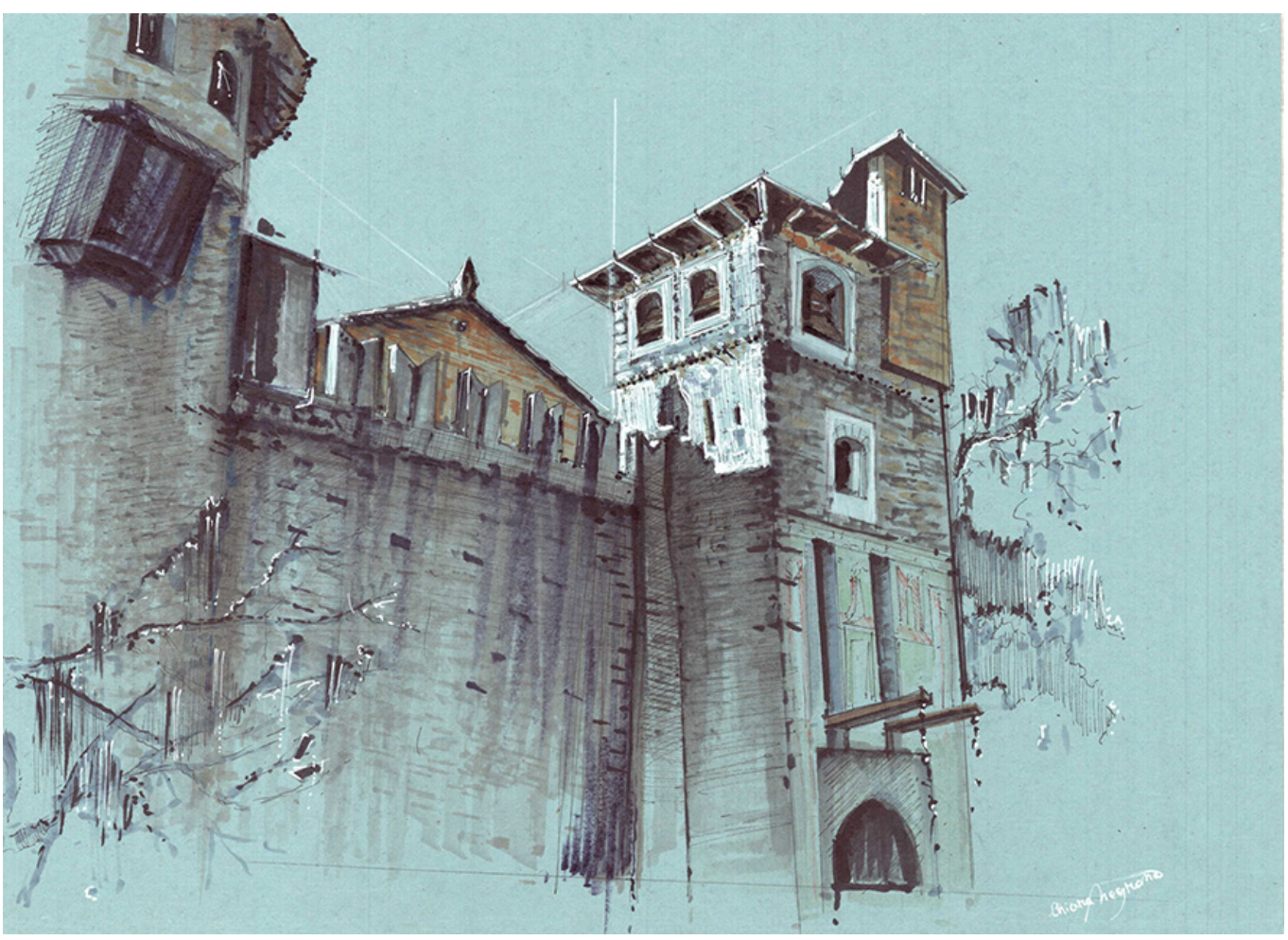


Fig. 4. Chiara Negrone:

la piazzetta all'inizio de

nucleo caratterizzata dalla

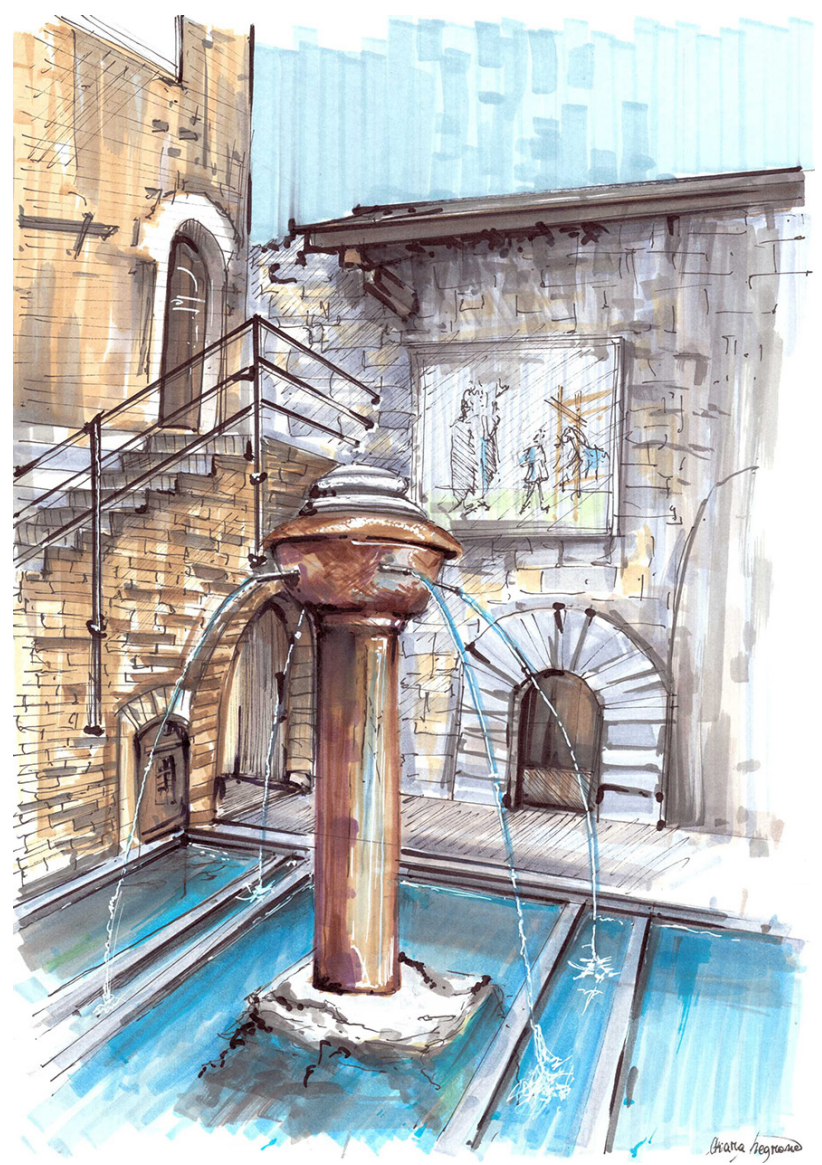

Fig. 5. Chiara Bossù: la torre d'ingresso al Borgo e particolari.
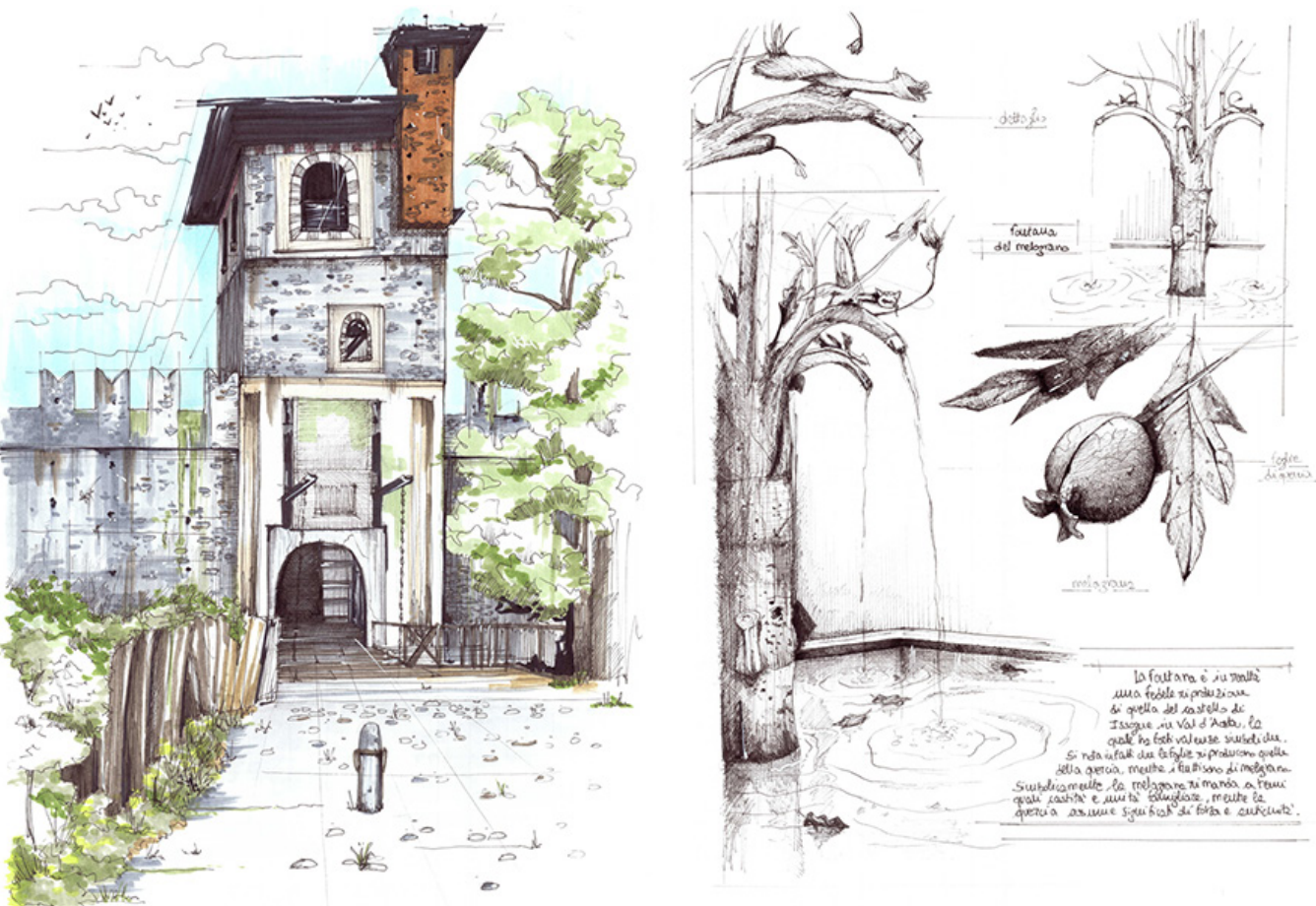


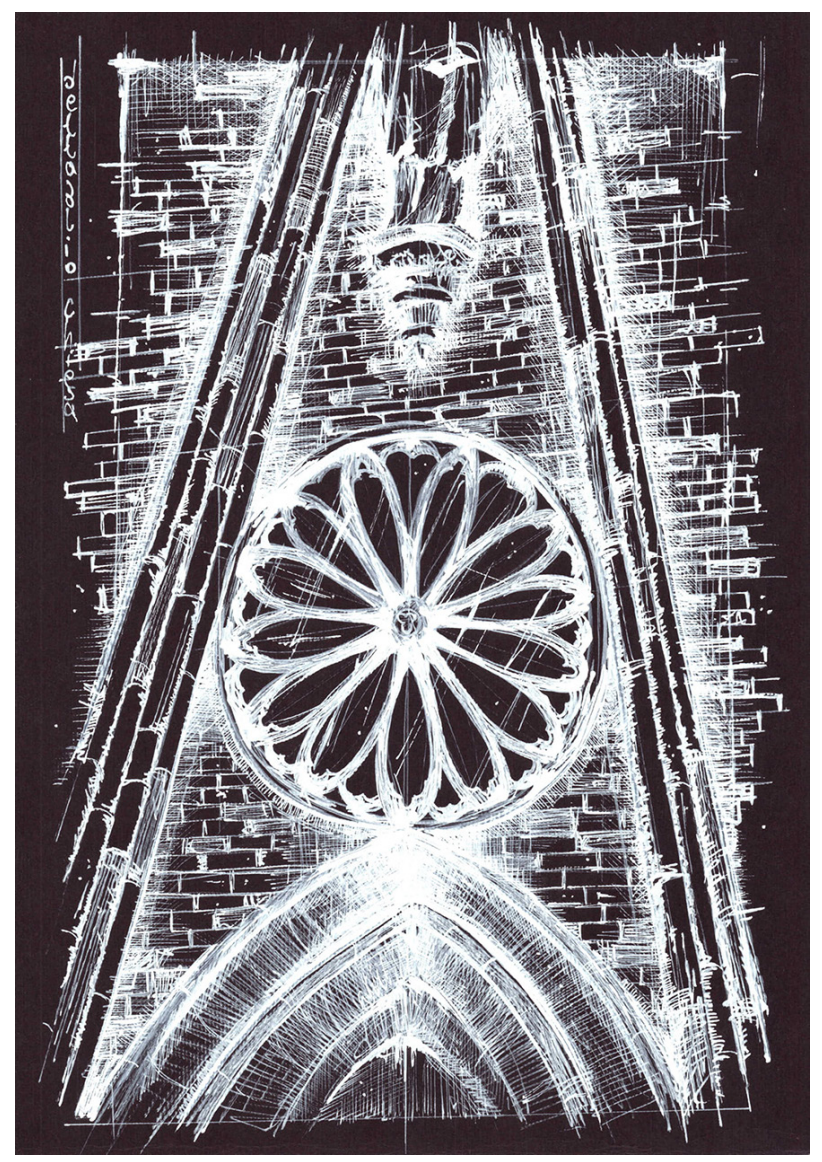

trascuriamo nella fase conoscitiva per l'involontario ruolo dominante attribuito alla vista, il progetto 'Oltre la visione' ha inteso avvicinare gradualmente gli studenti a un diverso modo di 'vedere' e di scoprire la realtà, attraverso una serie di esperienze nelle quali il fattore emotivo è stato il vero protagonista.

Per futuri architetti o artisti, per i quali la conoscenza e la comunicazione attraverso immagini sono il fondamento, sperimentare il peso delegato alla vista è stato testato nel primo sopralluogo alla scoperta del Borgo Medievale: un sopralluogo fatto ad occhi chiusi. Gli studenti hanno infatti percorso l'intero nucleo accompagnati a piccoli gruppi da noi docenti, cercando di scoprirlo attraverso i movimenti, il tatto, i suoni e i rumori, ovvero cogliendone gli elementi fisici ma anche l'atmosfera, interpretando le varie sensazioni percepite (fig. 9). Un percorso fatto di buio, ma soprattutto di nuove sensazioni, mai considerate o vissute prima. Poche ore dopo questo primo sopralluogo al Borgo gli studenti lo hanno ripercorso a occhi aperti, rivivendolo con stupore, in un'alternanza tra rispondenze e diversità percepite. Quest'esperienza percettiva li ha condotti ad approfondire il modo di conoscere quanto ci circonda, e di capire come alcune sue realtà costituiscano un caposaldo per muoversi o, al contrario, siano un ostacolo per chi si muove senza vedere, avvicinandoli alla fase successiva del progetto, la più emozionante e arricchente [5]. Le parole dell'architetto Grazia Baroni, per la quale le immagini sono state protagoniste nella formazione e nel lavoro, hanno dato un significato più profondo e ampio a quanto i ragazzi hanno provato nella loro breve esperienza al buio. Lei, con grande generosità, ha infatti guidato gli studenti a scoprire quel mondo da non vedenti nel quale da alcuni anni vive: in una lezione ne ha trattato diversi aspetti, da quelli più pratici a quelli più umani, cercando di far comprendere ai ragazzi il suo modo di 'vedere' il Borgo oggi, tra ricordi vaghi, un po' annebbiati, e piccole parti comprese tattilmente, sconnesse dalla contestualizzazione ambientale di cui ha solo sensazioni vaghe, soprattutto in base al movimento corporeo o ai suoni e alla loro risonanza. 


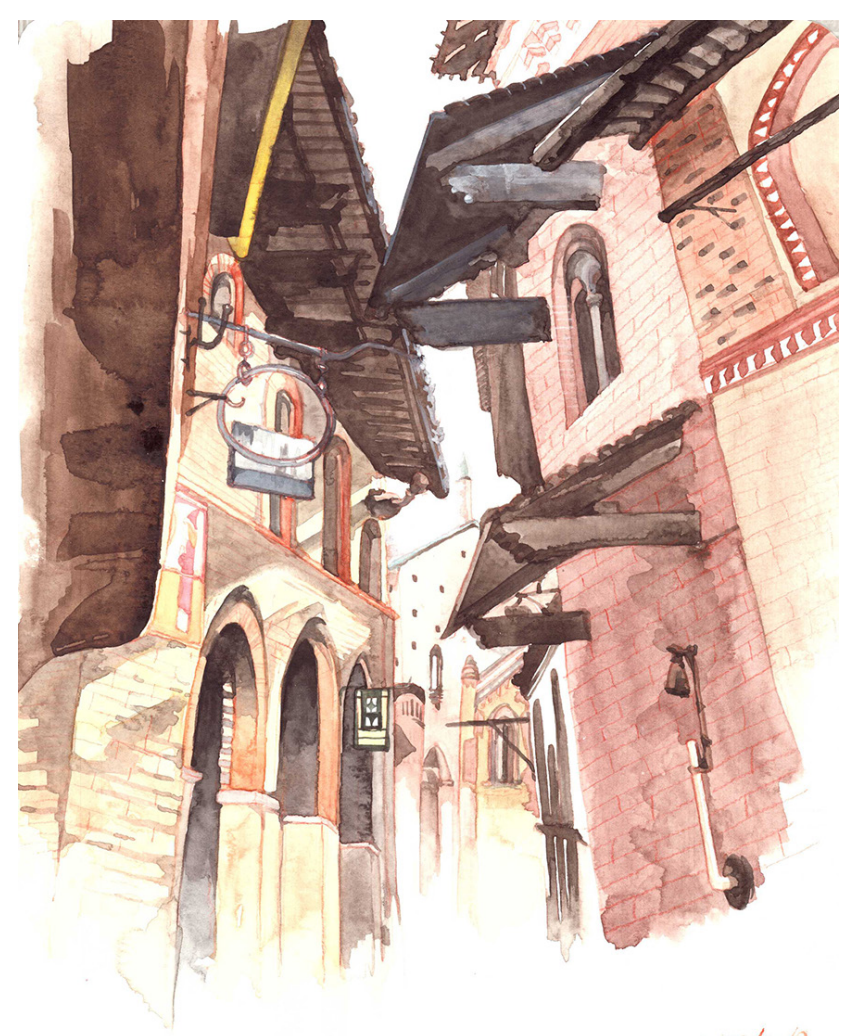

$25 / 02 / 2019$

Fig. 8. Amine Ben Hamida: vista di uno degli angoli più suggestivi realizzata

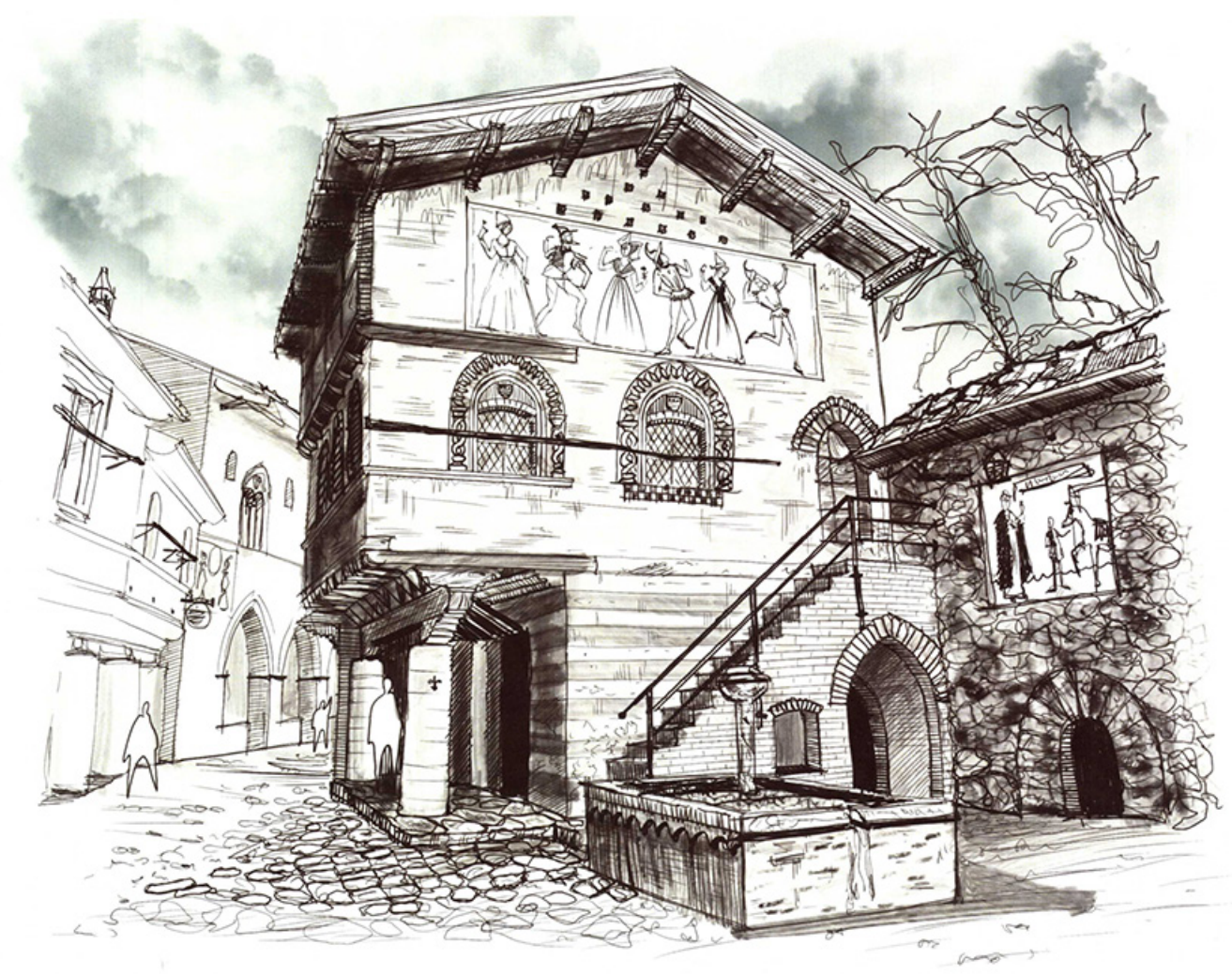


II tentativo di comprendere un altro modo di vedere architetture e luoghi (utile anche a superare le barriere mentali dovute spesso alla non conoscenza dell'altro, che si sovrappongono a quelle materiali rendendo più complessa la vita di chi ha difficoltà oggettive) è stato poi sviluppato nella creazione di un progetto grafico-pittorico guidato da Claudio Rabino. Un progetto in cui gli studenti hanno provato a 'diventare' gli occhi e le mani di Grazia, nel tentativo di restituire su otto grandi tele un percorso alla scoperta del Borgo, narrato attraverso la sua visione odierna [6]. II percorso disegnato e dipinto si dipana attraverso la sequenza degli elementi del Borgo Medievale da lei riconosciuti, visualizzandoli come frammenti che qua e là compaiono in immagini isolate e decontestualizzate, avvolti in una sorta di bruma che interpreta la nebulosità dei suoi ricordi e delle odierne percezioni. Ciò che Grazia ricorda o percepisce più nettamente è interpretato graficamente con colori marcati, mentre i suoi riferimenti tattili o acustici sono realizzati in rilievo [7] (fig. I0).

Nelle tele il Borgo è descritto a partire dal verde del parco (in parte ricordato e percepito dai suoni e dall'aria), per poi interpretarne il ricordo quasi fiabesco in una vista d'insieme di torri, merlature e dal ponte levatoio; ponte che è il protagonista della terza tela, di cui sono evidenziati cromaticamente e in rilievo le assi del pontile e le catene, elementi compresi tattilmente. Altrettanto in rilievo e con colori marcati risultano il passaggio del rigagnolo attraversato all'entrata e il bordo ad archetti pensili della fontana della quarta tela, risultati riferimenti tattili e dell'orientamento acustico, mentre l'edificio a fianco rimane avvolto nella nebbia dei ricordi. In un'altra tela vi è poi la via porticata, di cui emergono le colonne che la fiancheggiano e, nella successiva, lo scorcio caratterizzato dalla chiesa, ove sono evidenziati i riferimenti tattili, come le formelle in cotto o lo zoccolo in pietra, nonché l'acciottolato che pavimenta l'invaso, mentre gli edifici antistanti risultano chiari solo nel portico [8]. A concludere questo percorso narrato attraverso scorci prospettici (perché Grazia concepisce lo spazio in prospettiva, come gli altri divenuti non vedenti) vi è la fontana del melograno, circondata dall'atmosfera medievale che lei sente nel Borgo, in cui le sembra di respirare la presenza di dame e musicanti. Nell'ultima tela viene poi descritta la zona terminale del percorso, nella quale Rabino ha poeticamente collocato la sagoma di Grazia Baroni che saluta D'Andrade, ringraziandolo per il suo viaggio nel passato (figg. II, I2). Quest'esperienza si è conclusa con un incontro in cui gli studenti hanno provato a farle rivivere il viaggio descrivendole e facendole toccare le tele, in cui i colori (e le loro tessiture tattili) hanno solo riverberato le sensazioni e le emozioni da lei provate e a noi donate [9].

Il progetto, tra percezione dei luoghi e disegno, pur nella sua brevità ha interpretato immagini viste o che vivono al buio, dando loro vita attraverso un disegno pittorico che le accomuna in un unico linguaggio espressivo. Si è realizzato così un percorso guidato dall'architettura e dall'ambiente ma anche dalle parole, che documenta ancora una volta quanto il disegno, in ogni sua espressione, sia uno strumento di comunicazione, in grado (citando ancora le parole di presentazione al Convegno) di "mettere in evidenza le conoscenze e le relazioni tra le idee, le parole e le cose".
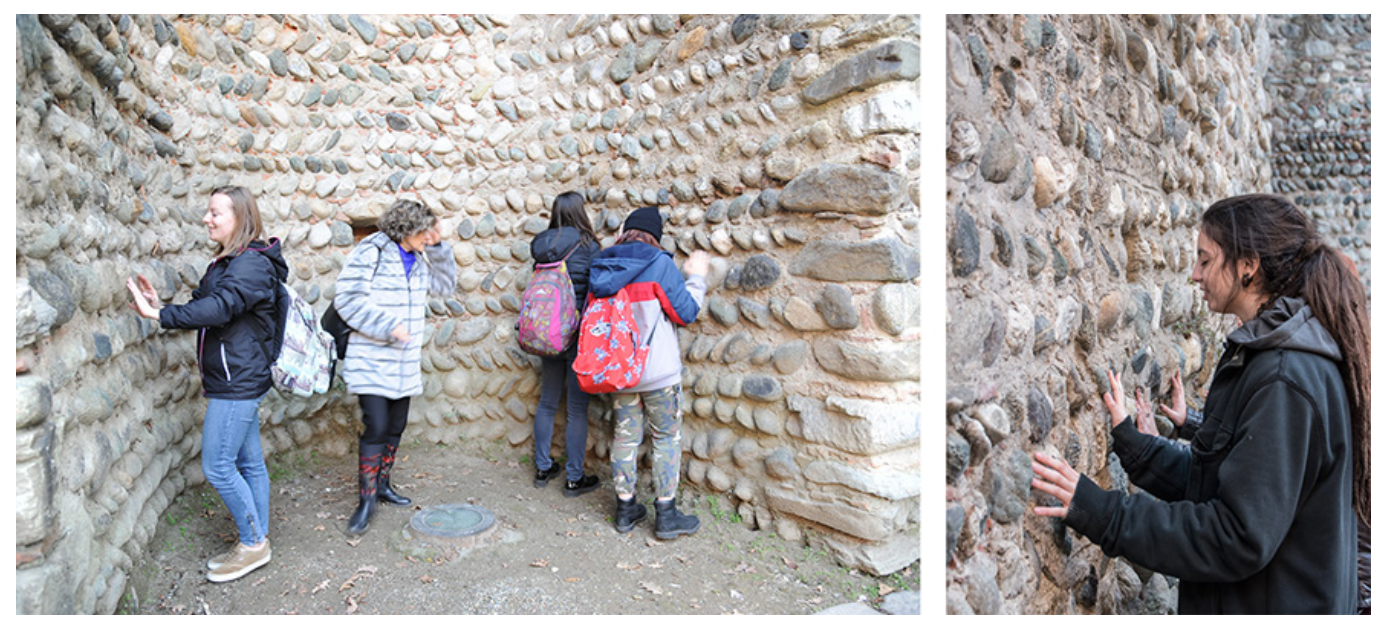
Fig. I0. Una delle parti in rilievo durante la realizzazione delle tele.



Fig. I I. Le otto tele del progetto Oltre la visione.



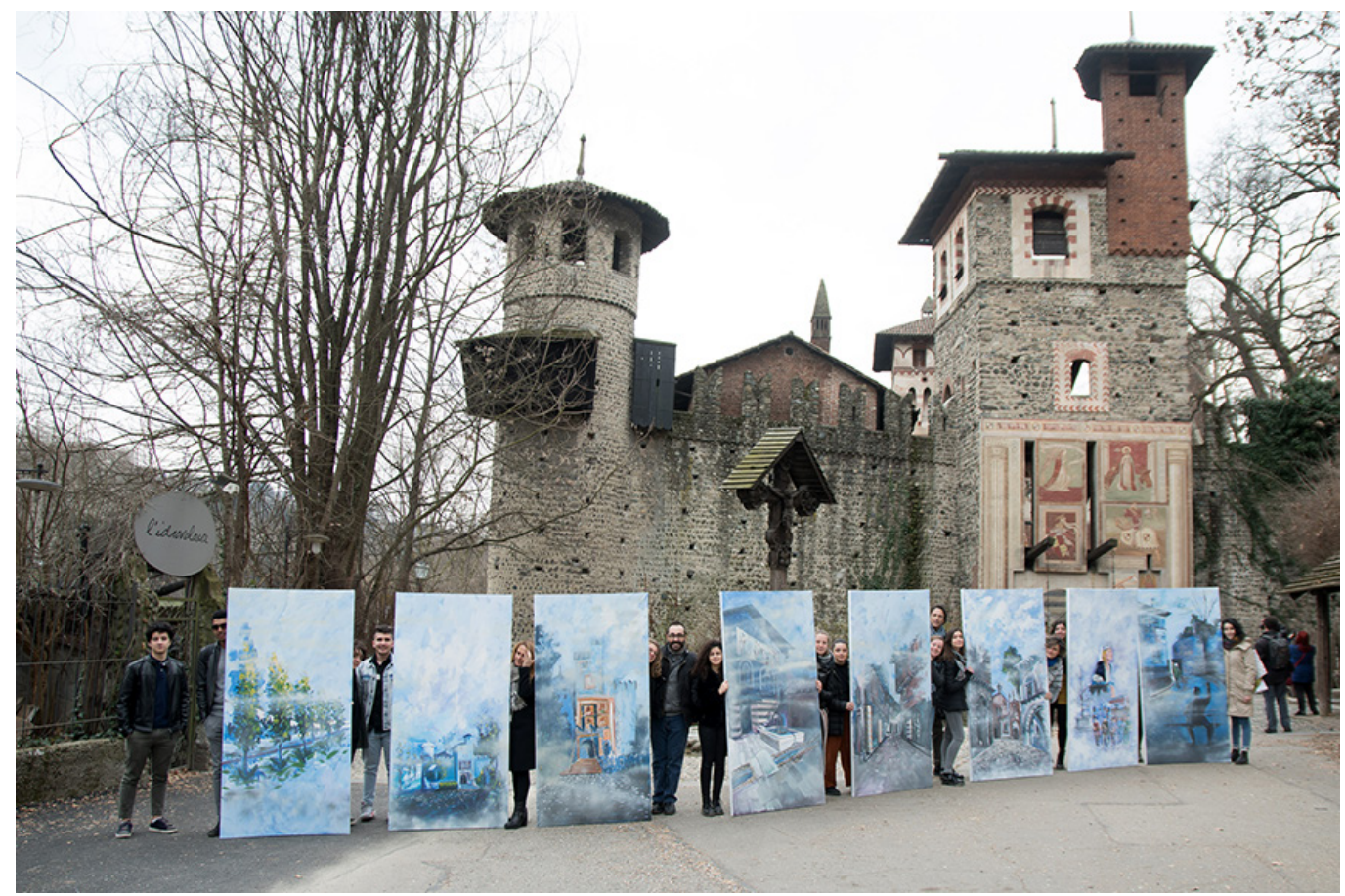

Note

[I] Mi hanno coadiuvata, con rara passione: Davide Anzalone, Ornella Bucolo, Pietro Merlo, Daniela Miron e Claudio Rabino.

[2] L'Esposizione, organizzata dalla Società promotrice dell'Industria Nazionale, fu concepita secondo i modelli internazionali delle esposizioni universali, intendendone il ruolo trainante per lo sviluppo industriale e del progresso tecnico. Non a caso infatti, oltre a D'Andrade, vennero coinvolti numerosi altri professionisti dai nomi illustri, come Alessandro Antonelli, Oreste Bollati, Riccardo Brayda e Carlo Ceppi.

[3] Archivio Storico della Città di Torino, Collezione Simeom, B 698, p. 10.

[4] Sono molto più noti i disegni di rilievo di D'Andrade, ma altrettanto significativi sono quelli dei suoi collaboratori. I disegni di Brayda qui riprodotti sono conservati presso: Politecnico di Torino, DIST-LSBC, Fondo Brayda, BRDI I e BRD22.

[5] L'esperienza 'a occhi chiusi' ha fatto testare in prima persona ai ragazzi quante barriere architettoniche si incontrano in ogni luogo non appositamente progettato, sensibilizzandoli al problema.

[6] II progetto del percorso grafico-pittorico, lungo e complesso da proporre in così breve tempo, è stato elaborato in primis da noi docenti dopo un sopralluogo insieme a Grazia Baroni, in cui attraverso la sua descrizione di sensazioni percepite e di ricordi, abbiamo individuato i suoi riferimenti: visivi (molto confusi), tattili, acustici, e altri. II tentativo di visualizzare le parole di Grazia è stato poi tecnicamente e artisticamente sviluppato da Claudio Rabino, che ha in seguito portato gli studenti a realizzare con lui le otto tele (cm 200x100 ciascuna).

[7] Per la realizzazione delle parti in rilievo è stato fondamentale il supporto del Laboratorio Modelli del Dipartimento Architettura e Design, e in particolare di Giovanni Berruto; altrettanto importante è stata la collaborazione con il Laboratorio Multimediale, soprattutto di Pietro Merlo che ha sviluppato la parte video del Workshop, nonché con il Laboratorio Rilievo e documentazione ancora del DAD, in particolare di Ornella Bucolo, fondamentale in ogni fase organizzativa e realizzativa de Workshop, insieme a Davide Anzalone del Liceo Cottini.

[8] La chiesa, a differenza di altri manufatti fedeli a un singolo fabbricato originale, si rifa a più edifici ecclesiastici, in cui si distinguono ad esempio le proporzioni della parrocchia di Verzuolo (presso Saluzzo), il cornicione in cotto e la finestra a sinistra tratte da San Giorgio a Valperga Canavese, o la slanciata ghimberga di San Giovanni Battista a Ciriè.

[9] L'esperienza è sintetizzata in un video realizzato da Pietro Merlo, visualizzabile (insieme a quello del Workshop) in: <https:// www.youtube.com/playlist?list=PLBHaDU0E_I GLwMsYdoBfstIVMC6OFtORA>.

\section{Riferimenti bibliografici}

Ceppi Enrico (20।4). La percezione dello spazio nei ciechi. La percezione acustica degli ambienti. In TifloPedia, Enciclopedia multimediale delle scienze tiflologiche, settembre 2014.

Ceppi Enrico (2016). La sensibilità tattile come fonte di percezione spaziale. In TifloPedia, Enciclopedia multimediale delle scienze tiflologiche, giugno 2016 
Chiavoni Emanuela (2018). Fonti visive documentarie per la conoscenza del paesaggio. In Bianconi Fabio, Filippucci Marco (a cura di). Il prossimo paesaggio. Realtà, rappresentazione, progetto. Roma: Gangemi Editore, pp. 57-62.

Chiavoni Emanuela (2018). I fondamenti teorici dell'analisi grafica. In Carlevaris Laura (a cura di). Ricerche 20/3-20/8. Dipartimento di Storia, Disegno e Restauro dell'Architettura. Roma: Gangemi Editore, pp. I5 I- 152.

Corradetti Maria Laura (20 I 8). La visita in un museo di una persona non vedente o ipovedente: strumenti cognitivi e rapporto con la guida museale. In Clionet. Per un senso del tempo e dei luoghi, 2, 20 I 8: <https://rivista.clionet.it/vol2/societa-e-cultura/ polis/corradetti-la-visita-in-un-museo-di-una-persona-non-vedente-o-ipovedente>.

Davico Pia (2019). II disegno per conoscere e raccontare l'architettura e l'ambiente. Roma:WriteUp Site.

Donato Giovanni (2006). Omaggio al Quattrocento. Dai fondi D’Andrade, Brayda, Vacchetta. Torino: Borgo e Rocca Medievale.

Giacosa Giuseppe (a cura di). ( 1884). Esposizione generale italiana, Torino 1884. Catalogo ufficiale della Sezione Storia dell'Arte. Guida Illustrata al Castello Feudale del Secolo XV.Torino:Tip.Vincenzo Bona.

Viglino Davico Micaela (1984). Benedetto Riccardo Brayda. Una riproposta ottocentesca del Medioevo. Torino: Centro Studi Piemontesi.

Virga Giovanna (2000). Considerazioni sperimentali sulla rappresentazione mentale dello spazio nei non vedenti. In Quaderni di ricerca didattica, pp. $183-197$.

\section{Autore}

Pia Davico, Politecnico di Torino, pia.davico@polito.it

Per citare questo capitolo: Davico Pia (2020). Oltre la visione: percezione, conoscenza, disegno, narrazione/Beyond vision: perception, knowledge, drawing, narration. In Arena A., Arena M., Brandolino R.G., Colistra D., Ginex G., Mediati D., Nucifora S., Raffa P. (a cura di). Connettere. Un disegno per annodare e tessere. Atti del $42^{\circ}$ Convegno Internazionale dei Docenti delle Discipline della Rappresentazione/Connecting. Drawing for weaving relationships. Proceedings of the 42th International Conference of Representation Disciplines Teachers. Milano: FrancoAngeli, pp. 3225-3246. 


\title{
Beyond Vision: Perception, Knowledge, Drawing, Narration
}

\author{
Pia Davico
}

Abstract

When we draw the environment surrounding us in order to measure it, understand it, or immortalize that which has most struck us, the marks we make on the paper do not remain detached from our emotions that - with different degrees of control and consciousness - complete and transliterate the main points of reference of visually absorbed tangible elements. Given its versatility of expression, the drawing is in fact the most suitable tool to express that which derives from our knowledge or perception, integrated with other stimuli that complete the ones provided by sight.

This was the basis of the learning experience provided in a Workshop I shall present hereby. Drawings were used to describe the Borgo Medievale (medieval village) of Turin at different levels of observation and knowledge, and have been paired with a perception experience initially 'in the dark', for which the eyesight has been purposely erased to better understand how the blind grasp the entity of their surrounding environment. The feelings felt by teachers and students have then served as the starting point to attempt to narrate (by means of a graphic/pictorial language that was purposely not required to define shapes with precision) how an - on this occasion blind - architect has perceived and captured the places visited together. The unprecedented experience (which I believe expresses the spirit of this Conference) has raised awareness in the future architects to design with greater consciousness and sensitivity, and has allowed each of the participants to give voice to their emotions and feelings by means of drawing.

Keywords

drawing, visual perception, knowledge, blindness, graphic/descriptive narration.

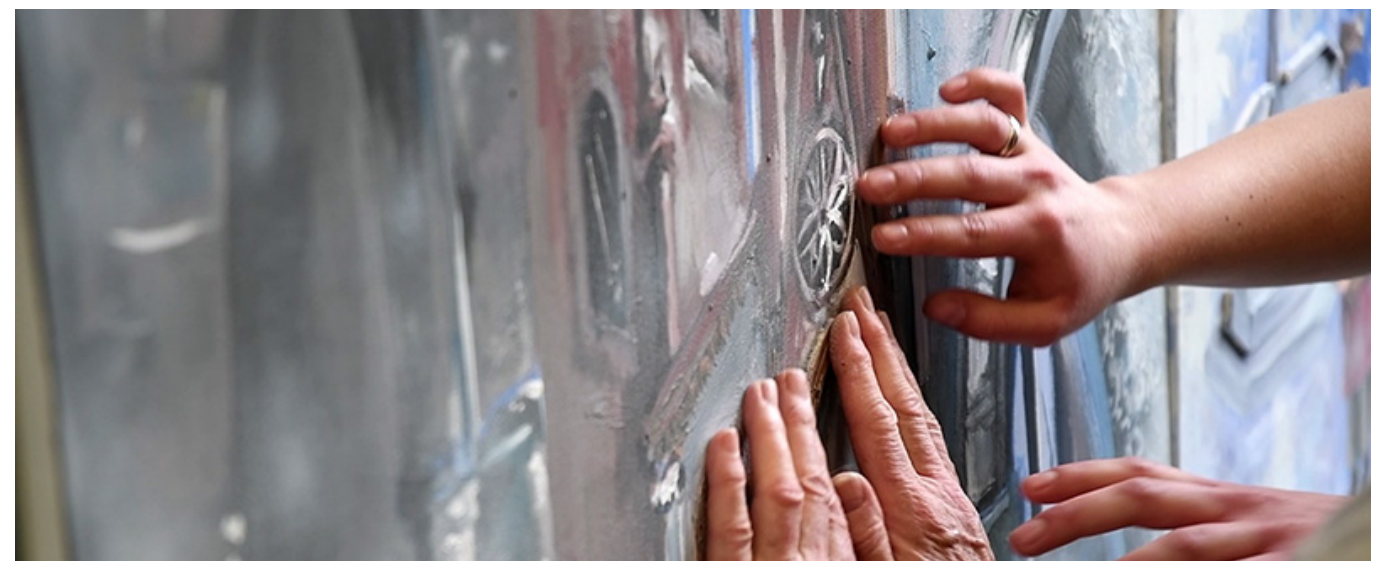




\section{Introduction}

Upon hearing some of the expressions used in presenting this Conference, I have immediately rediscovered the meaning of a learning experience I proposed a few months ago in the "Osservo, creo, racconto. Dialoghi tra Arte/Artistico e Architettura. Dal disegno alla fotografia al video" (I observe, I create, I narrate. Conversations between art/the art world and architecture. From drawing, to photography, to video) Workshop. For a number of years now, I have organized the Workshop so as to make the Bachelor's students from the Faculty of Architecture at the Turin Polytechnic work with the students from the Liceo Artistico Cottini (art-based high school); by means of their common interest for drawing, they experimented new graphic/expression means, and an enriching dialogue was created between students of two different academic contexts. This goal - which was reached in full throughout the Workshop - is indeed certified by the words "an eternal place of dialogue [...] in the eternal search to overcome conflict and divisions"; the meaning is amplified in the "Beyond vision" experience, as an integration of the Workshop activities. An innovative experience, with drawing as the common denominator, and with the purpose to develop attention and awareness both of setting perception and of the topic of visual impairment, highlighting aspects of the two that are in my opinion fundamental for the professional and personal growth of young men and women to whom vision, images, and understanding of that which surrounds them shall appear to be strictly interlinked factors.

As they worked at the Borgo Medievale di Torino throughout the entire Workshop activity, the students were given the chance to know the location in a new way, especially through the words of architect Grazia Baroni, formerly an Art History professor, who became blind some 10 years ago, who has guided the students in seeing the village "through her eyes", in a difficult balance between memories and that which she perceives today, having lost her eyesight.

It was a short experience, but very intriguing for the students, and useful to raise their awareness and make them understand in just how many ways reality can be "seen": a starting point, especially for future architects, stimulated to grasp the perceptive subjectivity of numerous aspects of the context examined and the variable relationship between its components, as well as the related physical and functional congruences and incongruences. Moreover, it has been a stimulus for all the students to search for new routes and modes of expression to identify and narrate diversity, learning to discuss and overcome eventual prejudiced differences.

Fig. I. Benedetto Riccardo Brayda: drawings of Aschieri house in Bussoleno, 18 April 1883.

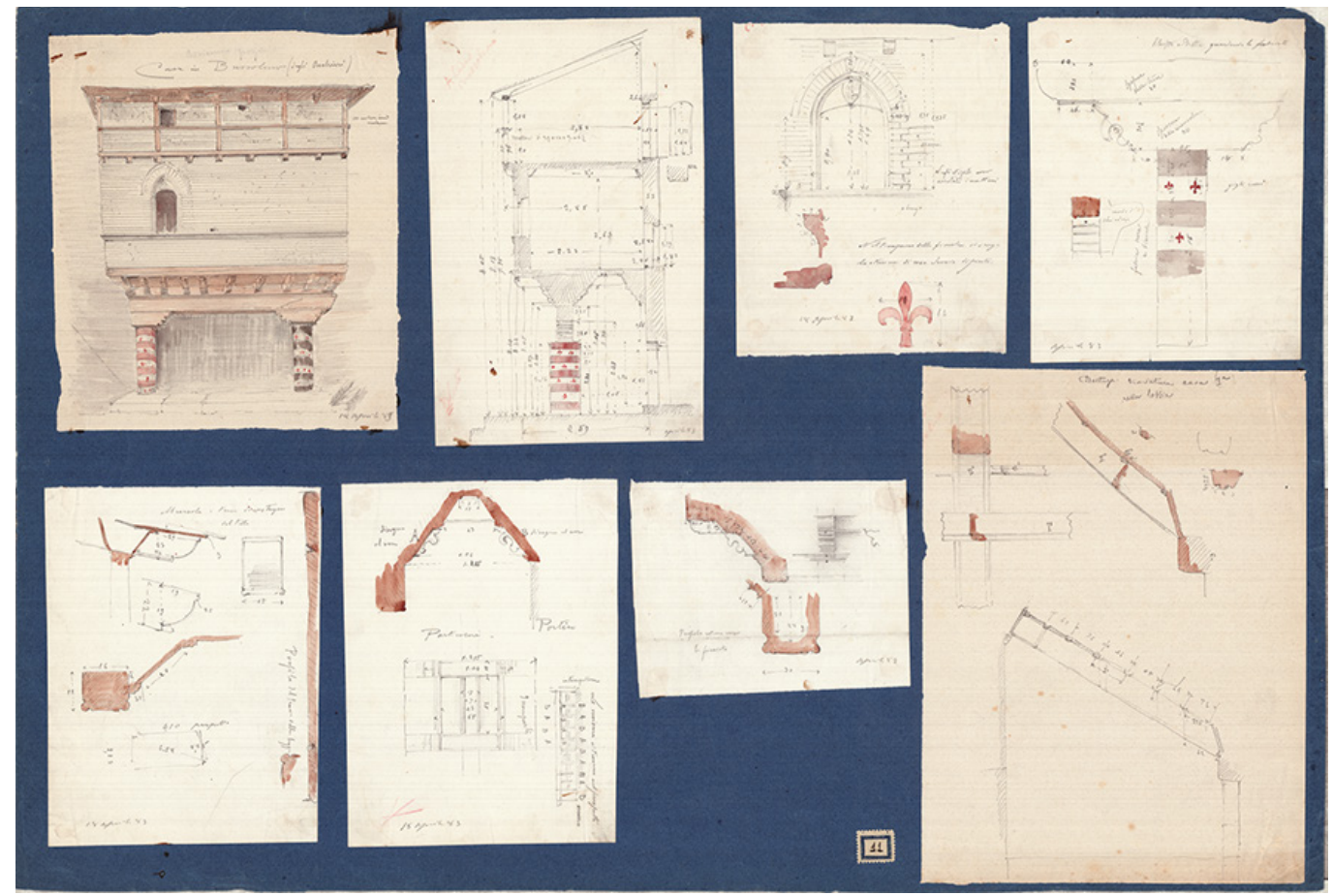




\section{Drawing the Borgo Medievale di Torino}

In this form of 'express' Workshop, the students were led by myself and the workgroup [I] to learn and graphically narrate, in just a few days, one of the most evocative locations of the city, enveloped by the green surroundings of the Parco del Valentino, in which the architecture and intricate lay-out of the urban system resemble a medieval environment, isolated in an identity suspended in time. The complex is based upon a design by Alfredo D'Andrade created for the Ancient Art category of the Esposizione Generale Italiana (general Italian expo), held in Turin in 1884, reconstructing a I 5th-century feudal village and its castle [2]. The construction was designed including strongly innovative (and as such widely contested) features, because it varied from the traditional model of exhibition of antiques, presenting instead "a treatise on the civilian and military life in I5th-century Piedmont, by means of a collection of furnished buildings, laid out in the form of a Castle (or rather a village with the dominating Citadel)" [3]; the construction techniques and every composition or decoration element of the built creation, as well as the related objects and furniture, faithfully replicated the original models, as a witness of the coeval rediscovery of medieval art and architecture proposed at the international level by Eugène Viollet-le-Duc and William Morris.

Indeed, Borgo Medievale diTorino is a village surrounded by crenelated and semi-ruined defensive walls, protected by a moat, with the castle and a tower-door with a drawbridge. Even nowadays it appears as if from a fairy tale, surrounded by the park and overlooking the Po riverbank, and is particularly interesting to discover, experience, and draw. The environmental connotation, in a balance between built and natural environment, is offered by a careful reproduction of spaces, architectures, and details true to the original, offered with philological precision following a meticulous surveying campaign by D'Andrade himself and others [4] (figs. I, 2) involving medieval constructions in the Piedmont and Aosta Valley regions, documented by still-existing drawings [Donato 2006]. The village boasts skilful scenery effects, expressed by means of both the planimetric-volumetric setup - i.e. in the perspective effect of the porticoed walkway, to perceptively increase its length, or the fortress erected on a little hill - and of the homes built only at the front like true stage curtains (with the exception of the Casa di Avigliana and Casa di Borgofranco homes which are built in full).

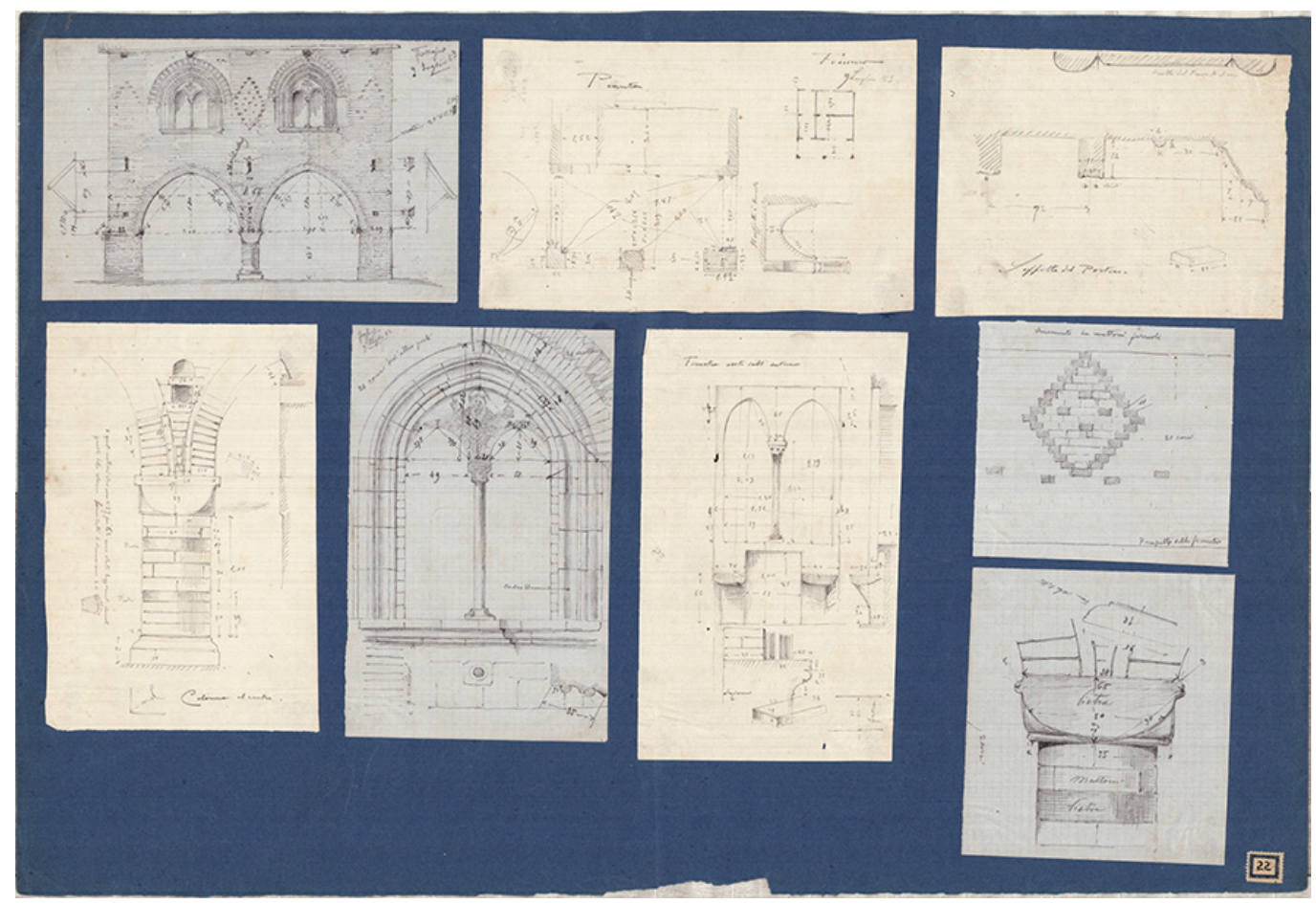


To make the centre even more alive and realistic, there are the workshops along the porticoed road, originally designed for handicraft activities, and that today recall the medieval atmosphere thanks to the deadened noises of their small spaces and of the portico which they face, or at an olfactory level, with the scent of leather seeping from one of the doors. The location, of an undoubtful appeal due to its exceptionality compared to the urban reality surrounding it, was chosen to stimulate multi-scale observation skills in the students, ranging from the landscape to the architectural details, and in attempt to capture even the intangible distinguishing features, and depict them by means of graphic/expressive personal interpretations. Indeed, the drawings produced in the five frenetic days of the Workshop demonstrate, in short, how the youngsters have perceived and gotten to know the medieval village, performing graphic interpretation even by means of techniques new to them, completed by photographs and video material, and the narration of environmental and architectural beauty through various languages of expression. Moreover, debate and discussion between students of a different academic background has stimulated their graphic creativity as an expression of their thoughts (figs. 3-8). This itinerary between knowledge and pictorial narration brought to a conclusion the "Beyond vision" experience, aimed at considering even the intangible elements that affect the way we grasp that which surrounds us, and reflecting on the perceptive ability of ourselves and others, which is essential to those designing architectures and places, and at the same time helps to better comprehend the 'vision' of a blind person, and understand how much 'different ways of seeing' shed light on certain traits of reality that are often not grasped or even ignored.

\section{Beyond vision}

This unprecedented experience involves certain aspects of theory of perception surveying and is based upon the assumption that when we look at a place or an architecture we do not remain unaffected by the perception of feelings and related emotive involvement that go beyond that which we see: this shows - even involuntarily- in the graphic interpretation of our drawing [Davico, Chiavoni 20 I8].

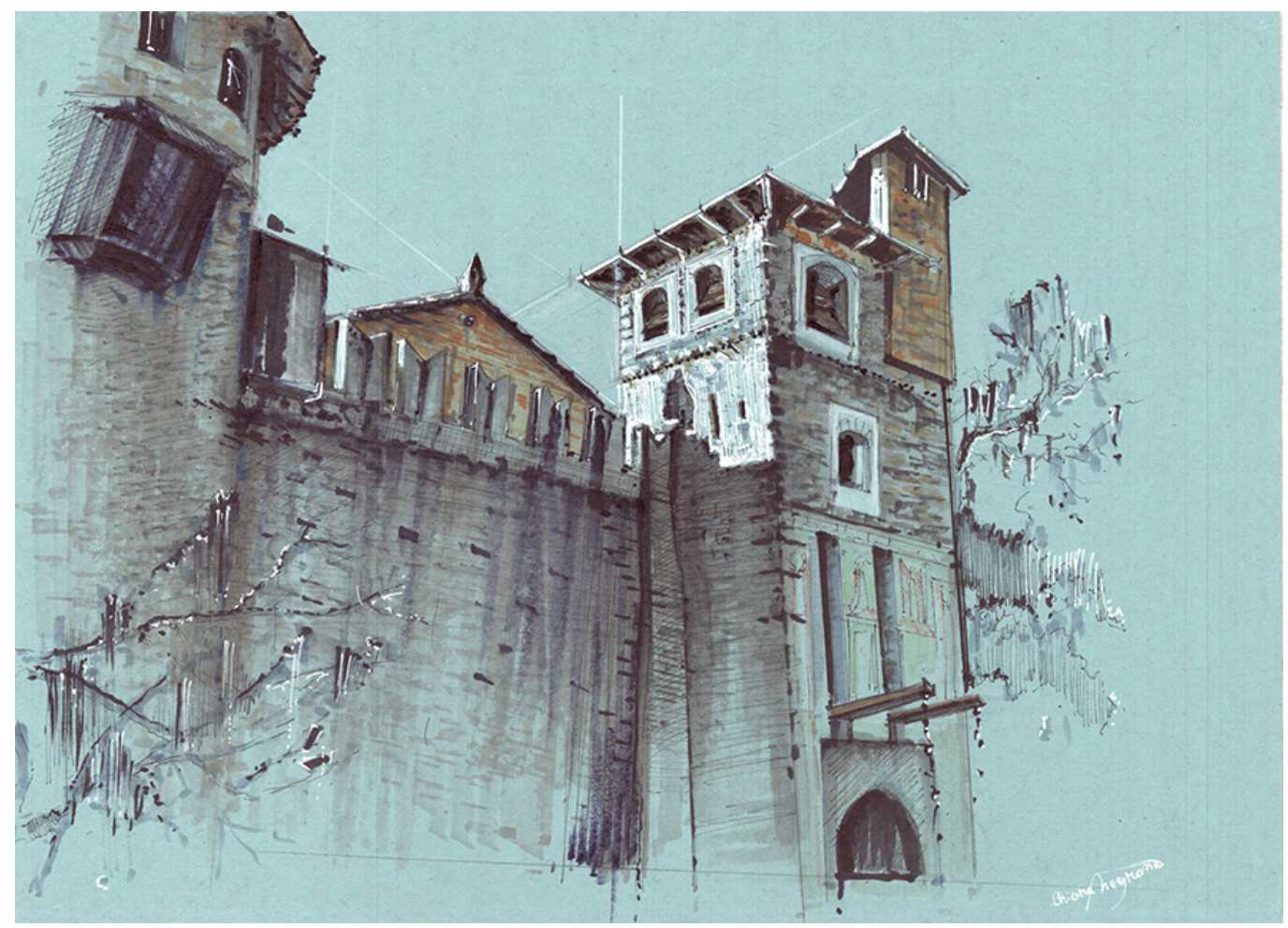


Fig. 4. Chiara Negrone: the little square et the beginning of the burg characterized by th fountain.

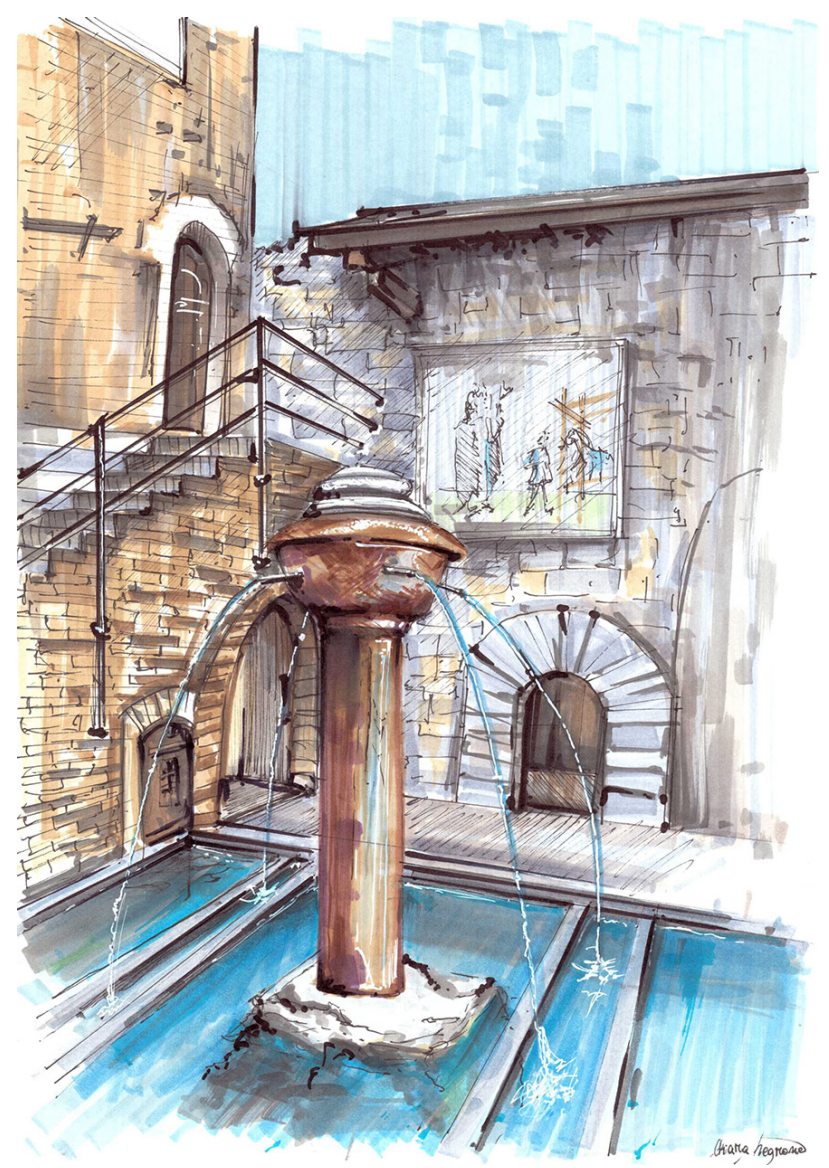

Fig. 5. Chiara Bossù: the entrance tower to the
Borgo and details.
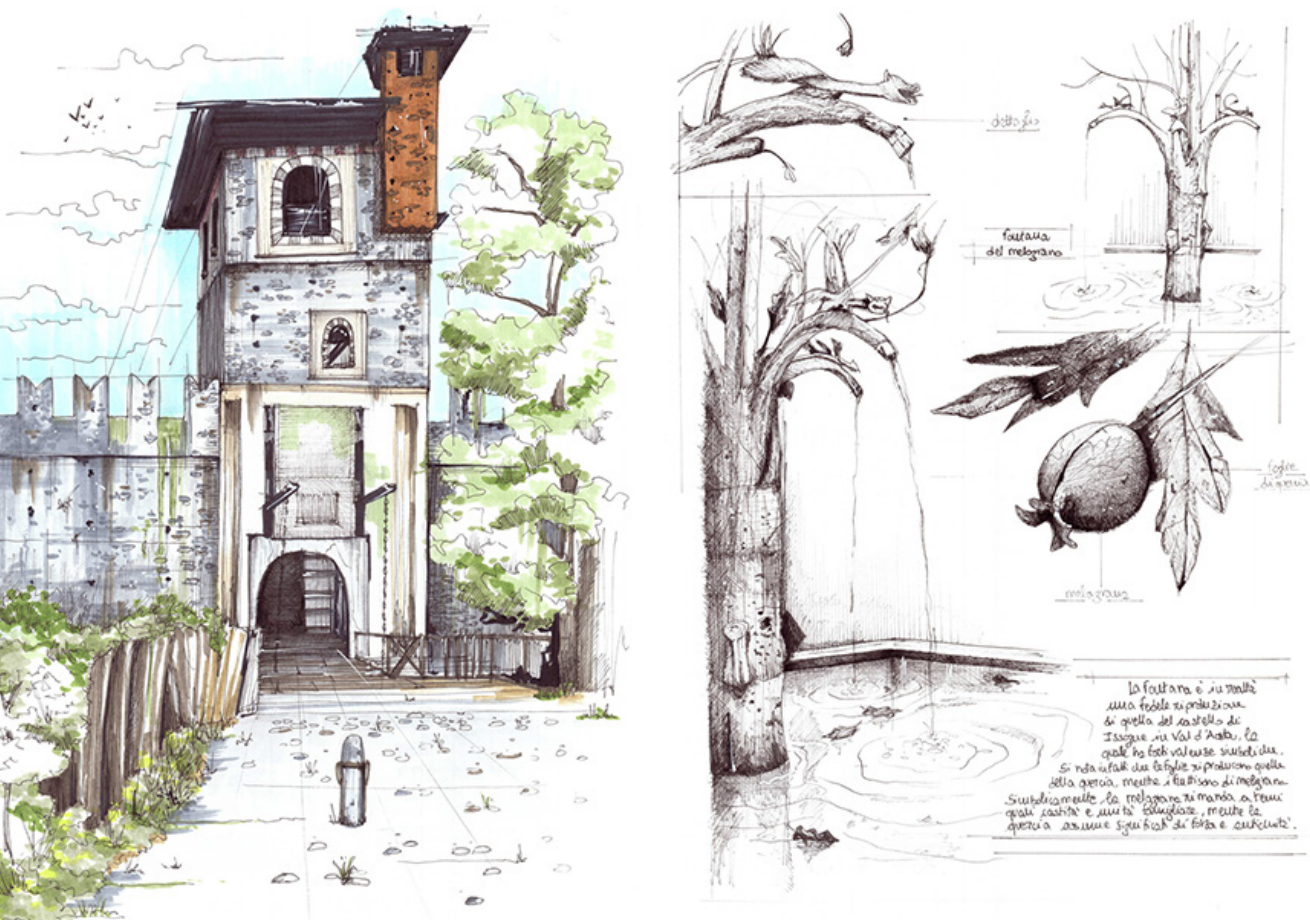


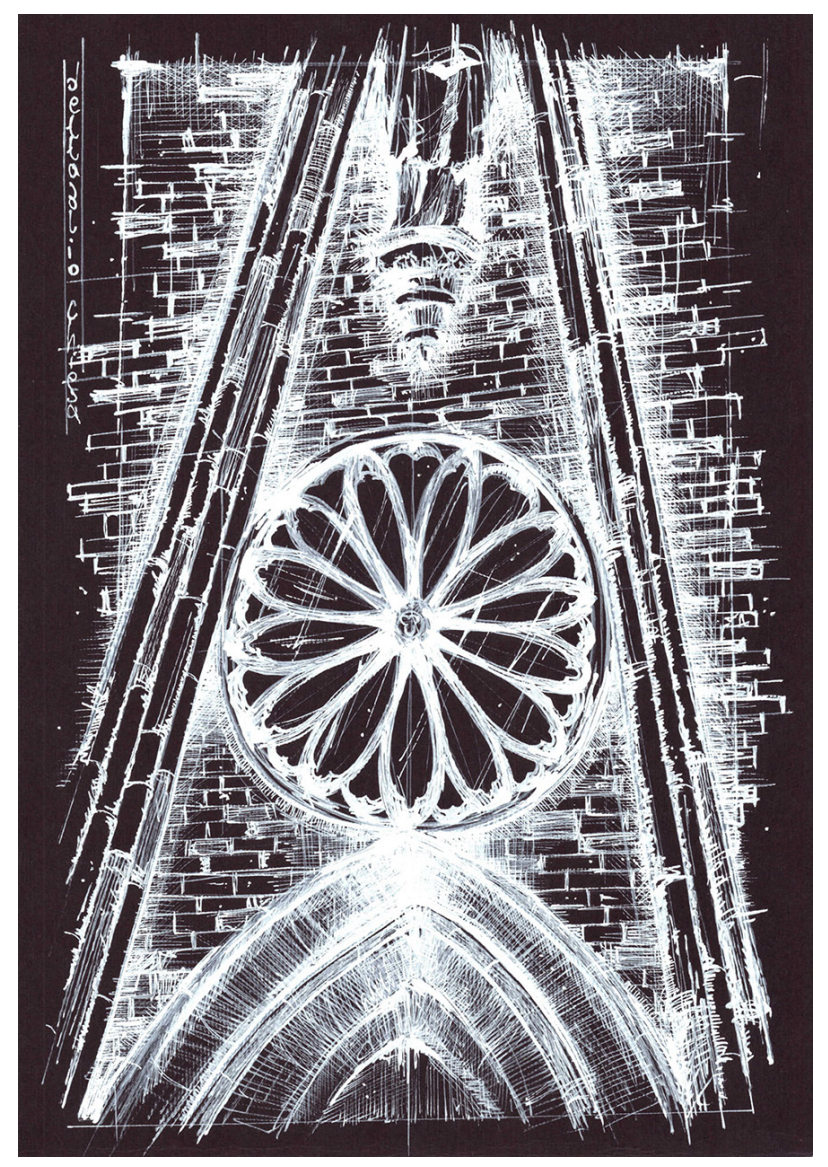

A plethora of intertwined feelings affects our perception of a location, and in turn our way of 'seeing'. To discover that which - at least in part - we normally ignore in the cognitive phase due to the dominant role assigned to eyesight, the "Beyond vision" project has set to gradually attract students towards a different way of 'seeing' and discovering reality by means of a series of experiences in which the emotive factor was the true protagonist.

The future architects or artists, for which knowledge and communication by means of images is a founding element, underwent a test of the importance given to eyesight by means of the initial survey of Borgo Medievale di Torino: a survey performed with their eyes closed. In fact, the students walked across the entire structure in small groups, accompanied by us lecturers, and tried to explore it by means of motion, touch, sounds, and noises, namely by absorbing its physical elements but also its atmosphere, and interpreting the various feelings perceived (fig. 9). A blind visit, but full of sensations never considered or experienced before. Only a few hours after this survey of the village, the students walked across it once again but with their eyes open, re-experiencing it with surprise, in a succession of perceived correspondences or differences. This perceptual experience has led them to further investigate the ways of knowing that which surrounds us, and to understand how some of its elements are fundamental to human movement, while others are - oppositely - obstacles for those who move without seeing. This led them to the next, most exciting and enriching step of the project [5]. The words of architect Grazia Baroni, for whom images have been crucial to training and profession, have given a deeper and broader meaning to that which the young women and men have lived in their short experience 'in the dark'. With great generosity, she indeed guided the students to the discovery of the world of the blind she has experienced for the past decade: in her lesson, she dealt with different aspects, ranging from the most practical to the most human, in an attempt to make the students understand her way of 'seeing' the medieval village today, in a mix of vague, slightly hazy memories, and small parts 
Fig. 7. Federica Emili: perspective of the narrow street of the Borgo.

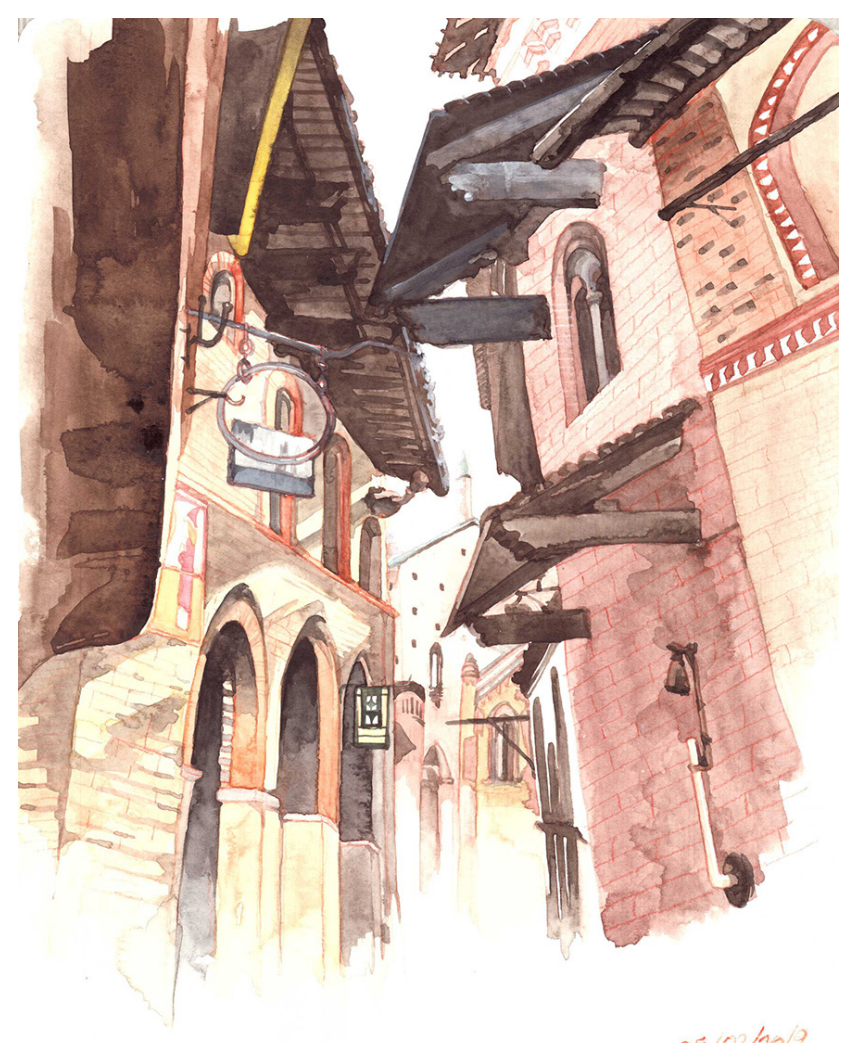

$25 / 02 / 2019$

Fig. 8. Amine Ben Hamida: view of one of the most suggestive corners made with graphics tablet

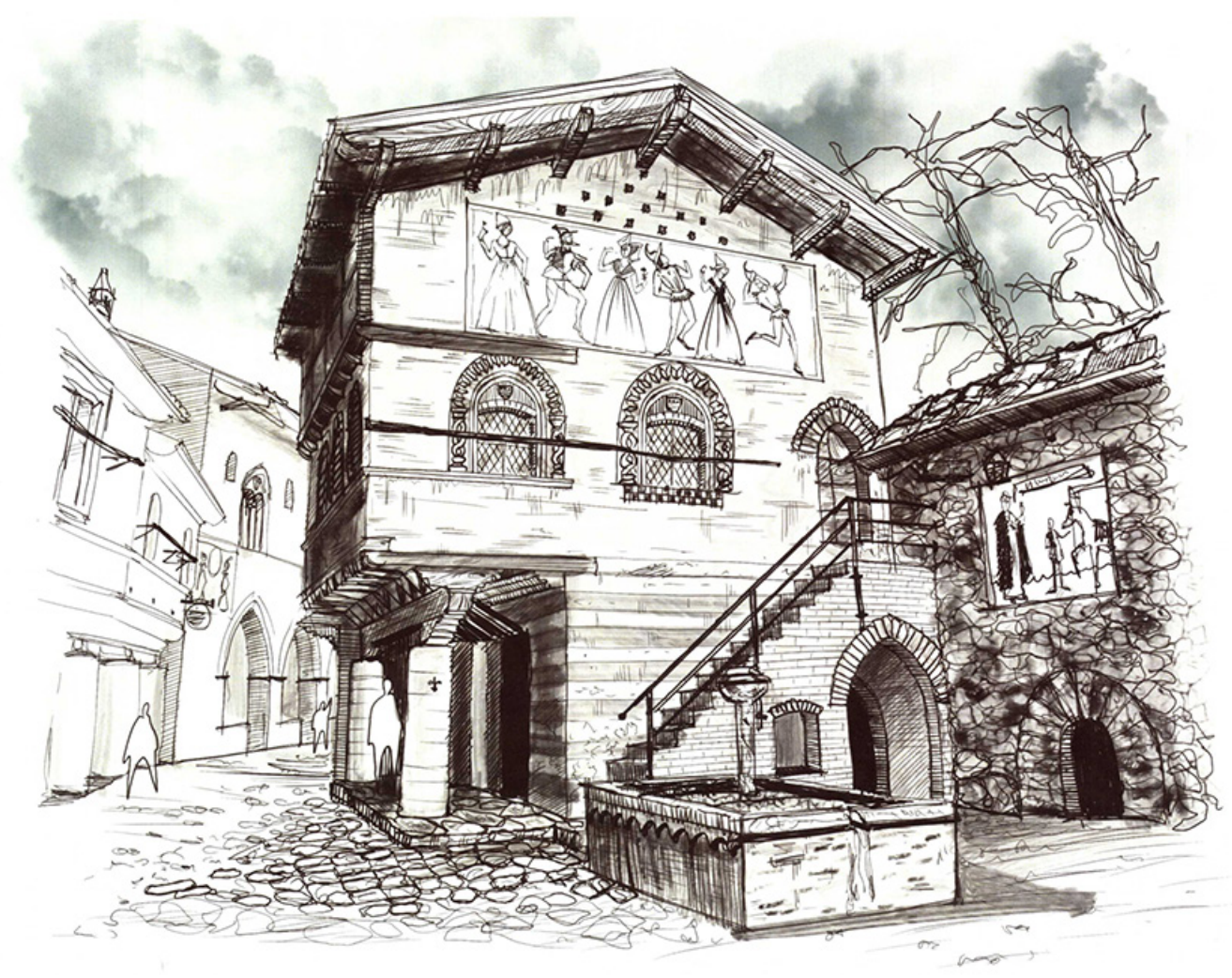


perceived by means of touch, disconnected from the environmental contextualization of which she only has a rough idea, especially based upon bodily movement or by sounds and their resonance.

The attempt to understand a different way of seeing architectures and places (which is also useful to overcome the mental barriers often related to not knowing the other, which overlap with the physical barriers that make the lives of those who have objective difficulties more complex) has moreover been developed with the creation of a graphic/pictorial project led by Claudio Rabino. A project in which the students tried to 'become' Grazia's eyes and hands, resulting in the production of 8 large canvases portraying a path to the discovery of Borgo Medievale di Torino, as narrated through Grazia's current vision [6]. The drawn and painted itinerary unravels with the sequence of elements of the village that she recognizes, visualizing them as fragments that appear here and there in an isolated and decontextualized image, wrapped in a kind of mist representing the fogginess of her memories and current perception. That which Grazia remembers or perceives more clearly was depicted with strong colours, while her tactile or acoustic points of reference were created in raised-relief [7] (fig. I0).

In the canvases, the village is described beginning with the green colour of the park (in part remembered and in part perceived through the sounds and air), then interpreted as the almost fairy-tale memory of a panoramic view of towers, crenels, and the drawbridge; the latter is the protagonist of the third canvas, in which the deck and chains - elements that are perceived through touch - were represented chromatically and in raised-relief. The creek crossed upon entrance and the Lombard band of the fountain - recorded as tactile and acoustic points of orientation - were also depicted using raised-relief and with strong colours, while the construction at the side of the fountain remains sheathed in the haze of memories. Another canvas bears the portico with its flanking columns, and the next artwork shows the church landscape, for which certain tactile points of reference - such as the cotto tiles or the stone plinth, as well as the cobblestones distinguishing the square - are highlighted, whilst only the porticoes of the adjacent buildings turn out to be clear [8]. To end this path - narrated by means of perspective drawings (in that Grazia views space in perspective, as all those who have lost their eyesight) - there is the Fontana del Melograno ('pomegranate fountain), surrounded by the medieval atmosphere the architect feels in the village, where she feels as if breathing the presence of damsels and minstrels. In the final canvas, there is the end of the itinerary, in which Rabino has poetically placed the silhouette of Grazia Baroni, saying good-bye to D'Andrade and thanking him for her journey in the past (figs. I I, I2). The experience was brought to conclusion by means of a meeting in which the students have attempted to make the architect re-live the journey, describing and making Grazia touch the canvases, on which the colours (and their tactile seam) have only reverberated the feelings and emotions experienced by her and offered to us [9].
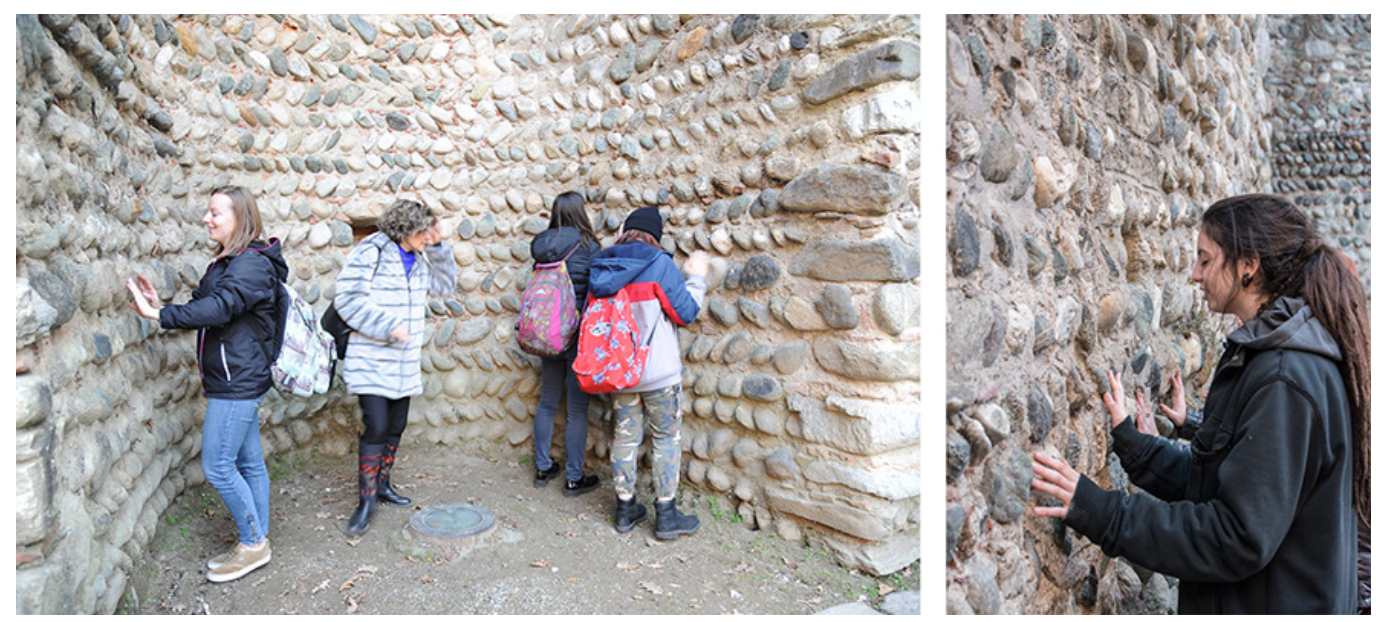
Fig. 10. One of the parts in relief during the making of the canvases.

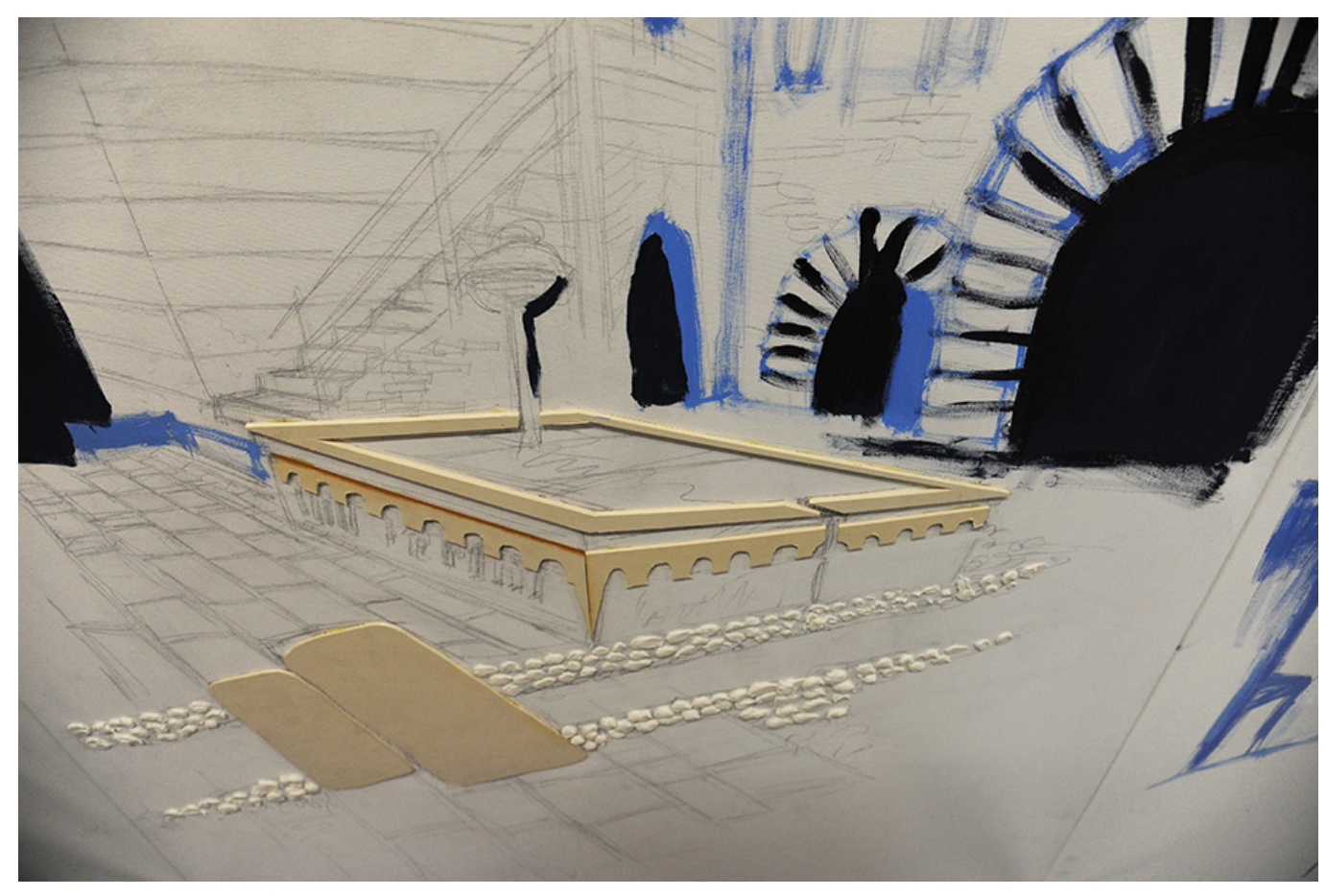

Fig. I I.The eight canvase of the project Oltre

visione (Beyond the

vision).
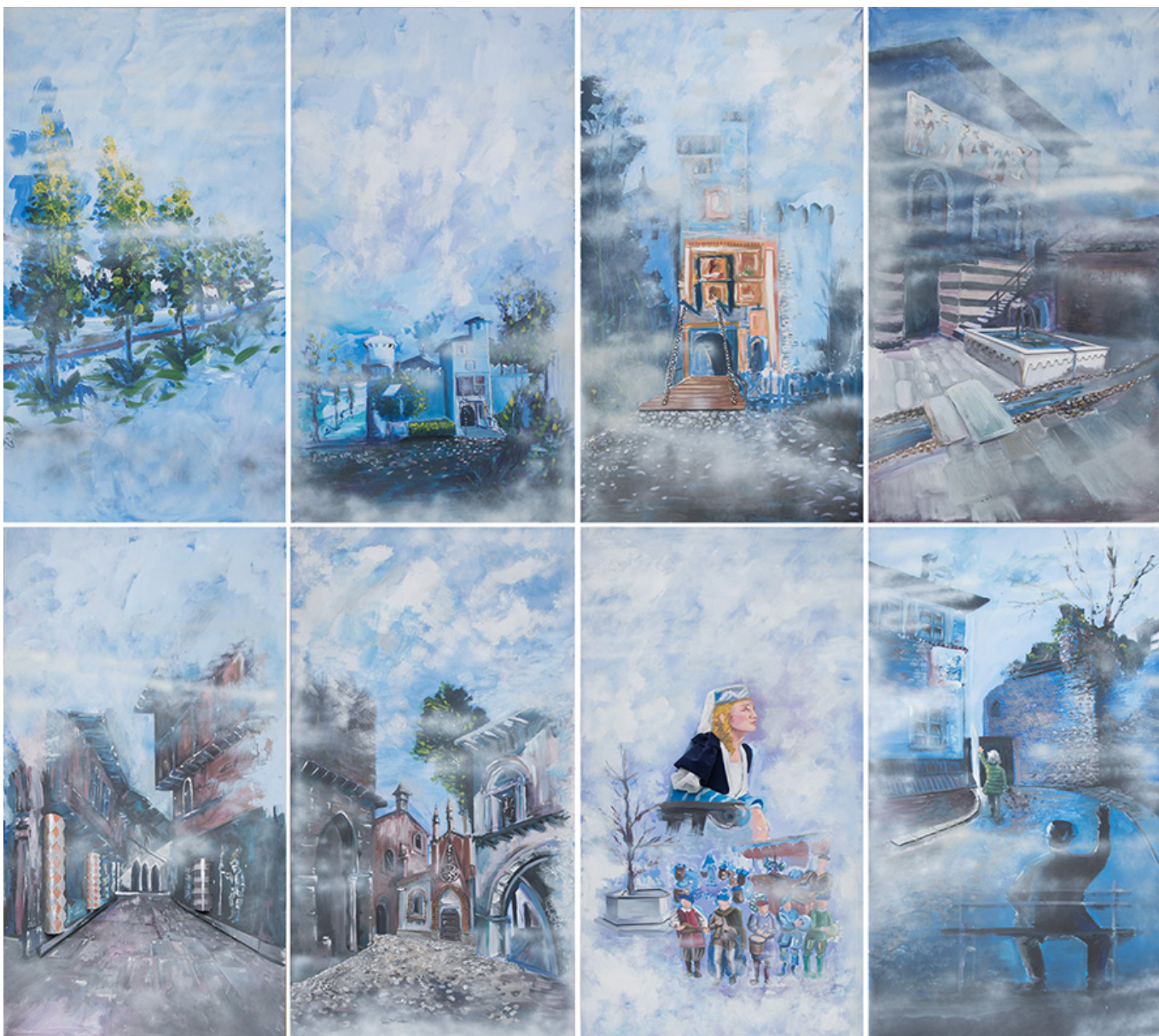


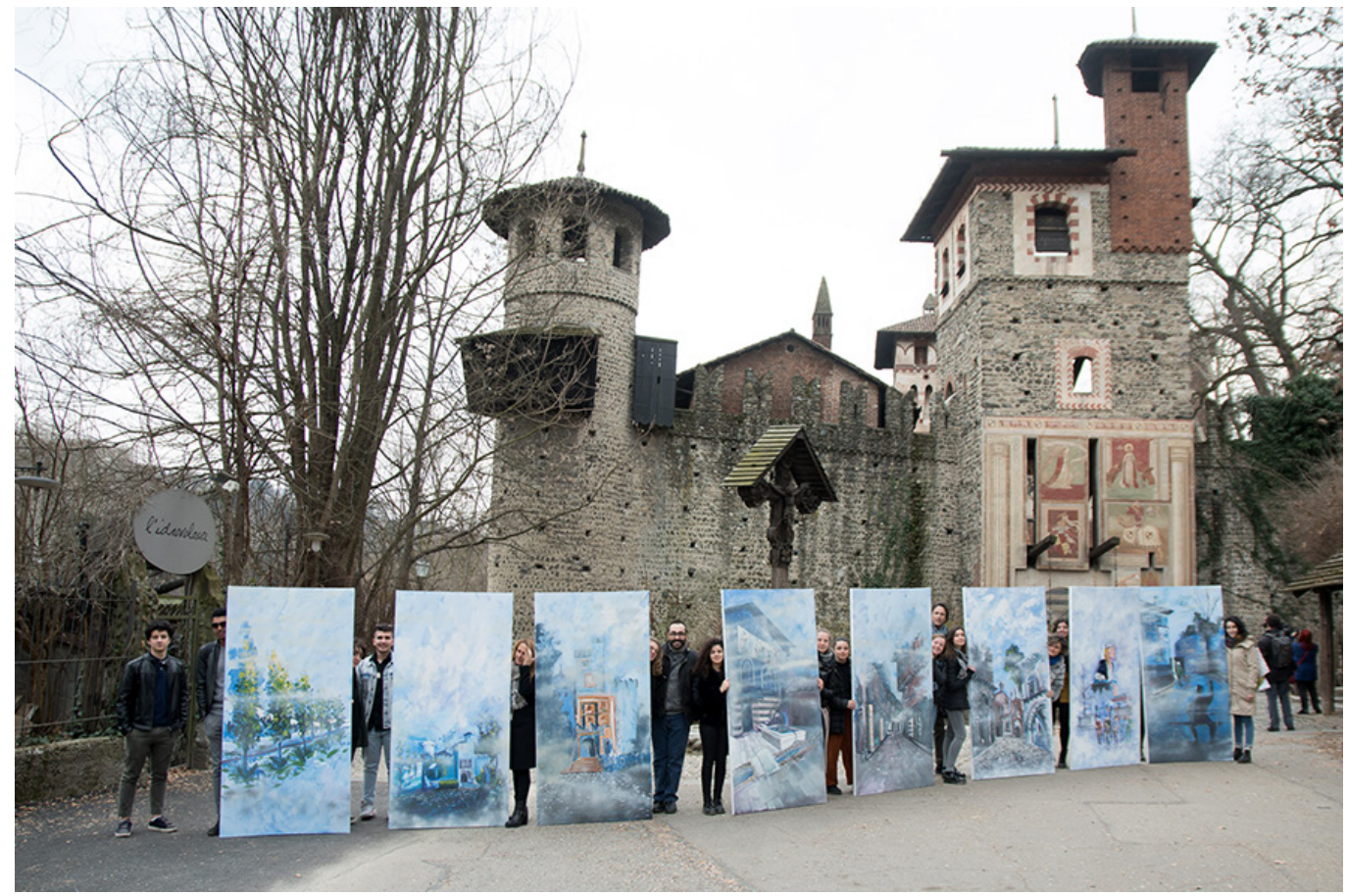

Though short, this project of perception and drawing of places has produced an interpretation of images experienced or that still exist in the darkness, giving life to them by means of a pictorial drawing that combines them all through a single artistic language. Thus, we created a path guided by architecture and the environment, but even words, which once again proves how drawing, in every form, is a communication tool able (again quoting the Conference presentation) to "highlight knowledge and relationships between ideas, words, and things".

\section{Notes}

[I] Davide Anzalone, Ornella Bucolo, Pietro Merlo, Daniela Miron, and Claudio Rabino have supported me with their rare passion for the subject.

[2] The expo, organized by the Società Promotrice dell'Industria Nazionale (company for the promotion of the Italian industry), was designed in accordance with the international models of universal expos, assigning it a driving role for industrial development and technical progress. In fact, it is no coincidence that - along with D'Andrade - a large number of illustrious professionals were involved, such as Alessandro Antonelli, Oreste Bollati, Riccardo Brayda, and Carlo Ceppi.

[3] Archivio Storico della Città di Torino (historic archive of the City ofTurin), Collezione Simeom, B 698, p. 10

[4] D'Andrade's technical drawings are much more well-known, but the ones produced by his co-operators are equally significant. Brayda's drawings as shown are stored at the Turin Polytechnic, DIST-LSBC, Fondo Brayda, BRDII e BRD22.

[5] The 'blind-folded' experience allowed the young men and women to witness in first person how many architectural barriers one meets in a place which is not designed specifically, which raised their awareness on the issue.

[6] The design for the graphic/pictorial path - which was long and complicated to develop in such a short time - was created above all by us professors upon performing a survey with Grazia Baroni, during which we identified - by means of the description of the feelings felt and her memories - her points of reference: visual (quite confused), tactile, acoustic, and others. The attempt to visualize Grazia's words has then been technically and artistically developed by Claudio Rabino, who later led the students in creating the 8 canvases $(200 \times 100 \mathrm{~cm}-78.67 \times 39.4$ in - each) with him.

[7] To create the raised-relief parts, fundamental support was offered by the Laboratorio Modelli (model lab) at the Department of Architecture and Design (DAD) of the Turin Polytechnic, and - in particular - Giovanni Berruto; an equally important cooperation was established with the Laboratorio Multimediale (multimedia lab) - and in particular Pietro Merlo, who developed the video part of the Workshop - as well as the Laboratorio Rilievo e Documentazione (survey and documentation lab) again at the DAD, and in particular di Ornella Bucolo, who was essential in every organizational and executive phase of the Workshop, together with Davide Anzalone of Liceo Cottini high school. 
[8] As opposed to the other constructions, which are true to a single original edifice, the church was designed as a combination of different religious buildings, among which we may distinguish the proportions of the Verzuolo (Saluzzo, Cuneo) parish church, the cotto cornice and the left window inspired by San Giorgio in Valperga Canavese (Turin), or the slender wimperg from San Giovanni Battista in Ciriè (Turin).

[9] The experience was summarized in a video by Pietro Merlo, viewable (along with the film of the Workshop) at: <https:// www.youtube.com/playlist?list=PLBHaDUOE_I GLwMsYdoBfstIVMC6OFtORA>.

\section{References}

Ceppi Enrico (20l4). La percezione dello spazio nei ciechi. La percezione acustica degli ambienti. In TifloPedia, Enciclopedia multimediale delle scienze tiflologiche, settembre 2014

Ceppi Enrico (2016). La sensibilità tattile come fonte di percezione spaziale. In TifloPedia, Enciclopedia multimediale delle scienze tiflologiche, giugno 2016

Chiavoni Emanuela (20।8). Fonti visive documentarie per la conoscenza del paesaggio. In Bianconi Fabio, Filippucci Marco (a cura di). Il prossimo paesaggio. Realtà, rappresentazione, progetto. Roma: Gangemi Editore, pp. 57-62.

Chiavoni Emanuela (2018). I fondamenti teorici dell'analisi grafica. In Carlevaris Laura (a cura di). Ricerche 2013-20/8. Dipartimento di Storia, Disegno e Restauro dell'Architettura. Roma: Gangemi Editore, pp. I5 I- I52.

Corradetti Maria Laura (20 I 8). La visita in un museo di una persona non vedente o ipovedente: strumenti cognitivi e rapporto con la guida museale. In Clionet. Per un senso del tempo e dei luoghi, 2, 20 18: <https://rivista.clionet.it/vol2/societa-e-cultura/ polis/corradetti-la-visita-in-un-museo-di-una-persona-non-vedente-o-ipovedente $>$.

Davico Pia (2019). II disegno per conoscere e raccontare l'architettura e l'ambiente. Roma:WriteUp Site.

Donato Giovanni (2006). Omaggio al Quattrocento. Dai fondi D’Andrade, Brayda, Vacchetta. Torino: Borgo e Rocca Medievale.

Giacosa Giuseppe (a cura di). (1884). Esposizione generale italiana, Torino I884. Catalogo ufficiale della Sezione Storia dell'Arte. Guida Illustrata al Castello Feudale del Secolo XV.Torino:Tip.Vincenzo Bona.

Viglino Davico Micaela (1984). Benedetto Riccardo Brayda. Una riproposta ottocentesca del Medioevo. Torino: Centro Studi Piemontesi.

Virga Giovanna (2000). Considerazioni sperimentali sulla rappresentazione mentale dello spazio nei non vedenti. In Quaderni di ricerca didattica, pp. 183-197.

\section{Author}

Pia Davico, Politecnico di Torino, pia.davico@polito.it

To cite this chapter. Davico Pia (2020). Oltre la visione: percezione, conoscenza, disegno, narrazione/Beyond vision: perception, knowledge, drawing, narration. In Arena A., Arena M., Brandolino R.G., Colistra D., Ginex G., Mediati D., Nucifora S., Raffa P. (a cura di). Connettere. Un disegno per annodare e tessere. Atti del $42^{\circ}$ Convegno Internazionale dei Docenti delle Discipline della Rappresentazione/Connecting. Drawing for weaving relationships. Proceedings of the 42th International Conference of Representation Disciplines Teachers. Milano: FrancoAngeli, pp. 3225-3246. 